Prepared in cooperation with the Kansas Department of Transportation

\title{
Precipitation-Frequency and Discharge- Frequency Relations for Basins Less than 32 Square Miles in Kansas
}

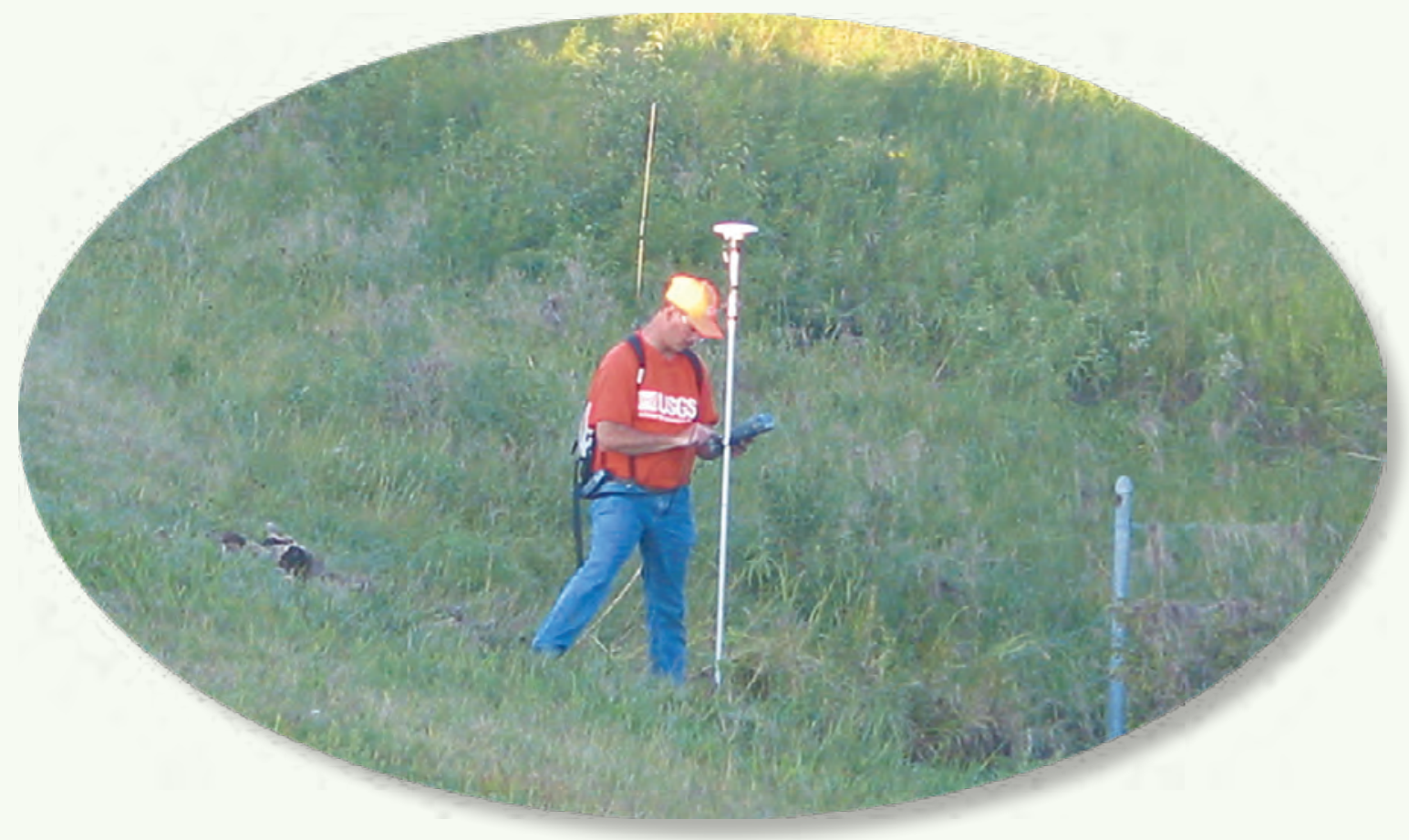

Scientific Investigations Report 2008-5112 
Cover photograph. Robert Gauger (USGS Hydrologic Technician, deceased) performing an indirect flood discharge survey on Jacobs Creek in Chase County, Kansas (photograph by Charles A. Perry, U.S. Geological Survey). 


\section{Precipitation-Frequency and Discharge- Frequency Relations for Basins Less than 32 Square Miles in Kansas}

By Charles A. Perry

Prepared in cooperation with the Kansas Department of Transportation

Scientific Investigations Report 2008-5112 


\section{U.S. Department of the Interior DIRK KEMPTHORNE, Secretary}

\section{U.S. Geological Survey \\ Mark D. Myers, Director}

U.S. Geological Survey, Reston, Virginia: 2008

Revised and reprinted: 2008

For product and ordering information:

World Wide Web: http://www.usgs.gov/pubprod

Telephone: 1-888-ASK-USGS

For more information on the USGS--the Federal source for science about the Earth, its natural and living resources, natural hazards, and the environment:

World Wide Web: http://www.usgs.gov

Telephone: 1-888-ASK-USGS

Any use of trade, product, or firm names is for descriptive purposes only and does not imply endorsement by the U.S. Government.

Although this report is in the public domain, permission must be secured from the individual copyright owners to reproduce any copyrighted materials contained within this report.

Suggested citation:

Perry, C.A., 2008, Precipitation-frequency and discharge-frequency relations for basins less than 32 square miles in Kansas: U.S. Geological Survey Scientific Investigations Report 2008-5112, 24 p. 


\section{Contents}

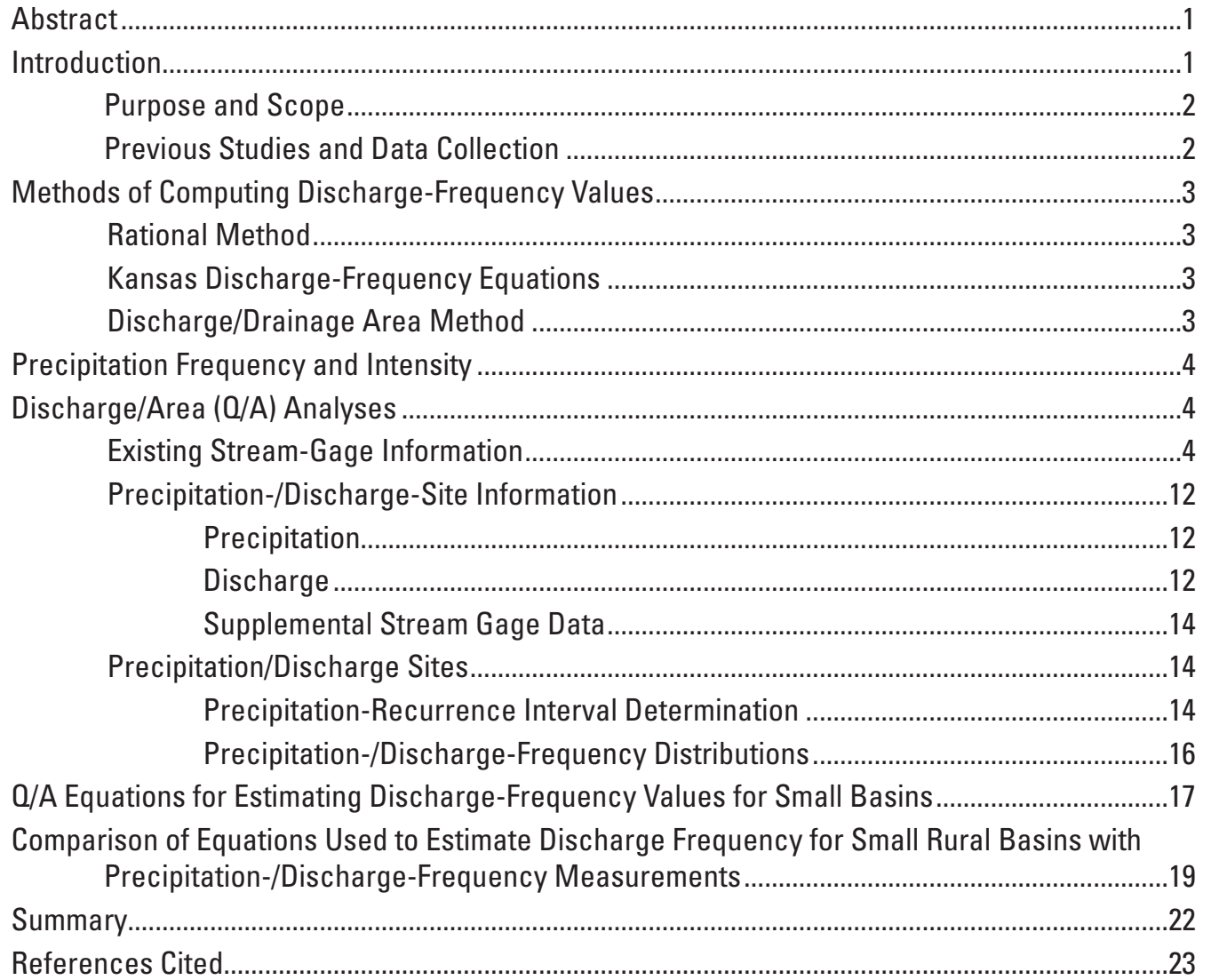

\section{Figures}

1. Map of $(A)$ stream-gaging stations with less than 32 square miles drainage areas used in discharge/drainage area ( $Q / A)$ discharge-frequency analysis, and (B) precipitation/ discharge sites in Kansas.

2-5. Graphs showing:

2. Simple ranked frequency distribution of discharge/drainage area $(Q / A)$ for gaged data, for the various quartiles of permeability $(A, D)$, channel slope $(B, E)$, and mean annual precipitation $(C, F)$ for basins of 5.4 to 32 square miles $(A, B, C)$, and basins of 0.17 to 5.4 square miles $(D, E, F)$.

3. Log Pearson III frequency distribution (skew=-0.9) for discharge/drainage area $(\mathrm{Q} / \mathrm{A})$ for gaged data for all basins less than 32 square miles, less than 5.4 square miles, and for 5.4 to 32 square miles.

4. Log Pearson III frequency distribution (skew=-1.1) for discharge/drainage area (Q/A) for gaged data by 1 st , 2nd through 3rd, and 4th quartiles of $(A)$ permeability, $(B)$ channel slope, and $(C)$ mean annual precipitation, for basins less than 5.4 square miles .....13 
5. Log Pearson III frequency distribution (skew=-0.9) for discharge/drainage area $(Q / A)$ for gaged data by 1 st , 2nd through 3rd, and 4th quartiles of $(A)$ permeability, $(B)$ channel slope, and $(C)$ mean annual precipitation for basins 5.4 to 32 square miles.

6. Example of 1-hour precipitation rate estimates from the Topeka, Kansas Weather Radar, (07:35 UTC, 02/10/2005)

7. Example of 3-hour precipitation estimates from the Topeka, Kansas Weather Radar, with superimposed basins, (12:12 UTC, 02/10/2005).

8-12. Graphs showing:

8. Precipitation-recurrence intervals for the Kansas City metropolitan area (modified from Young and McEnroe, 2006)...

9. Relation between the ratio of discharge/drainage area $(0 / A)$ values and precipitationrecurrence intervals, for $(A)$ all basins; $(B)$ basins less than 5.4 square miles ; and (C) basins 5.4 to 32 square miles.

10. Relation between ratio of discharge/drainage area $(\mathrm{Q} / \mathrm{A})$ and precipitation-recurrence intervals and stream gaged-data log Pearson III distribution (LP3) recurrence intervals for $(A)$ basins less than 5.4 square miles and $(B)$ basins between 5.4 and 32 square miles

11. Relation between ratio of discharge/drainage area $(\mathrm{Q} / \mathrm{A})$ and channel slope for basins less than 5.4 square miles using 5 -year precipitation-recurrence interval. 18

12. Relation between ratio of discharge/drainage area $(Q / A)$ and time of concentration for $(A) 5$-year precipitation-recurrence interval and $(B)$ 100-year precipitation-recurrence interval.

13. Flow charts comparing conventional regional discharge-frequency analysis to the alternative discharge to drainage area $(\mathrm{Q} / \mathrm{A})$ discharge-frequency analysis.

14-16. Graphs showing:

14. Relation between measured discharge and computed discharge values using the rational method

15. Relation between measured discharge and computed discharge values using Kansas discharge-frequency equations (KFFE).

16. Relation between measured discharge and computed discharge values using the discharge/drainage area $(0 / A)$ discharge-frequency equations developed in this report

\section{Tables}

1. Discharge stream-gaging stations in Kansas with basin areas less than 32 square miles and their basin characteristics

2. Precipitation/peak-discharge events 2004-2007, time of concentration, basin characteristics, and estimated or measured flow values.

3. Example of selection of 100-, 50-, and 25-year recurrence interval of ranked $0 / A$ for a single quartile

4. Multiple linear regression variables and coefficients for discharge/drainage are $(\mathrm{Q} / \mathrm{A})$ discharge-frequency equations developed in this report. 


\section{Conversion Factors}

\begin{tabular}{|c|c|c|}
\hline Multiply & By & To obtain \\
\hline \multicolumn{3}{|c|}{ Length } \\
\hline inch (in.) & 2.54 & centimeter $(\mathrm{cm})$ \\
\hline inch (in.) & 25.4 & millimeter $(\mathrm{mm})$ \\
\hline foot $(\mathrm{ft})$ & 0.3048 & meter $(\mathrm{m})$ \\
\hline mile (mi) & 1.609 & kilometer $(\mathrm{km})$ \\
\hline yard (yd) & 0.9144 & meter $(\mathrm{m})$ \\
\hline \multicolumn{3}{|c|}{ Area } \\
\hline square mile $\left(\mathrm{mi}^{2}\right)$ & 259.0 & hectare (ha) \\
\hline square mile $\left(\mathrm{mi}^{2}\right)$ & 2.590 & square kilometer $\left(\mathrm{km}^{2}\right)$ \\
\hline \multicolumn{3}{|c|}{ Flow rate } \\
\hline cubic foot per second $\left(\mathrm{ft}^{3} / \mathrm{s}\right)$ & 0.02832 & cubic meter per second $\left(\mathrm{m}^{3} / \mathrm{s}\right)$ \\
\hline $\begin{array}{l}\text { cubic foot per second per square mile } \\
{\left[\left(\mathrm{ft}^{3} / \mathrm{s}\right) / \mathrm{mi}^{2}\right]}\end{array}$ & 0.01093 & $\begin{array}{l}\text { cubic meter per second per square } \\
\text { kilometer }\left[\left(\mathrm{m}^{3} / \mathrm{s}\right) / \mathrm{km}^{2}\right]\end{array}$ \\
\hline cubic foot per day $\left(\mathrm{ft}^{3} / \mathrm{d}\right)$ & 0.02832 & cubic meter per day $\left(\mathrm{m}^{3} / \mathrm{d}\right)$ \\
\hline inch per hour (in/h) & 0.0254 & meter per hour $(\mathrm{m} / \mathrm{h})$ \\
\hline inch per year (in/yr) & 25.4 & millimeter per year $(\mathrm{mm} / \mathrm{yr})$ \\
\hline mile per hour $(\mathrm{mi} / \mathrm{h})$ & 1.609 & kilometer per hour $(\mathrm{km} / \mathrm{h})$ \\
\hline
\end{tabular}

Temperature in degrees Celsius $\left({ }^{\circ} \mathrm{C}\right)$ may be converted to degrees Fahrenheit $\left({ }^{\circ} \mathrm{F}\right)$ as follows:

$$
{ }^{\circ} \mathrm{F}=\left(1.8 \times{ }^{\circ} \mathrm{C}\right)+32
$$

Temperature in degrees Fahrenheit $\left({ }^{\circ} \mathrm{F}\right)$ may be converted to degrees Celsius $\left({ }^{\circ} \mathrm{C}\right)$ as follows:

$$
{ }^{\circ} \mathrm{C}=\left({ }^{\circ} \mathrm{F}-32\right) / 1.8
$$

Vertical coordinate information is referenced to the insert datum name (and abbreviation) here for instance, "North American Vertical Datum of 1988 (NAVD 88)."

Horizontal coordinate information is referenced to the insert datum name (and abbreviation) here for instance, "North American Datum of 1983 (NAD 83)."

Altitude, as used in this report, refers to distance above the vertical datum.

NOTE TO USGS USERS: Use of hectare (ha) as an alternative name for square hectometer $\left(\mathrm{hm}^{2}\right)$ is restricted to the measurement of small land or water areas. Use of liter (L) as a special name for cubic decimeter $\left(\mathrm{dm}^{3}\right)$ is restricted to the measurement of liquids and gases. No prefix other than milli should be used with liter. Metric ton (t) as a name for megagram (Mg) should be restricted to commercial usage, and no prefixes should be used with it. 



\title{
Precipitation-Frequency and Discharge-Frequency Relations for Basins Less than 32 Square Miles in Kansas
}

\author{
By Charles A. Perry
}

\section{Abstract}

Precipitation-frequency and discharge-frequency relations for small drainage basins with areas less than 32 square miles in Kansas were evaluated to reduce the uncertainty of discharge-frequency estimates. Gaged-discharge records were used to develop discharge-frequency equations for the ratio of discharge to drainage area $(\mathrm{Q} / \mathrm{A})$ values using data from basins with variable soil permeability, channel slope, and mean annual precipitation. Soil permeability and mean annual precipitation are the dominant basin characteristics in the multiple linear regression analyses.

In addition, 28 discharge measurements at ungaged sites by indirect surveying methods and by velocity meters also were used in this analysis to relate precipitation-recurrence interval to discharge-recurrence interval. Precipitationrecurrence interval for each of these discharge measurements were estimated from weather-radar estimates of precipitation and from nearby raingages. Time of concentration for each basin for each of the ungaged sites was computed and used to determine the precipitation-recurrence interval based on precipitation depth and duration. The ratio of discharge/drainage area $(\mathrm{Q} / \mathrm{A})$ value for each event was then assigned to that precipitation-recurrence interval.

The relation between the ratio of discharge/drainage area (Q/A) and precipitation-recurrence interval for all 28 measured events resulted in a correlation coefficient of 0.79 . Using basins less than $5.4 \mathrm{mi}^{2}$ only, the correlation decreases to 0.74 . However, when basins greater than 5.4 and less than $32 \mathrm{mi}^{2}$ are examined the relation improves to a correlation coefficient of 0.95 .

There were a sufficient number of discharge and radarmeasured precipitation events for both the 5-year (8 events) and the 100-year (11 events) recurrence intervals to examine the effect of basin characteristics on the Q/A values for basins less than $32 \mathrm{mi}^{2}$. At the 5-year precipitation-/dischargerecurrence interval, channel slope was a significant predictor $(\mathrm{r}=0.99)$ of $\mathrm{Q} / \mathrm{A}$. Permeability $(\mathrm{r}=0.68)$ also had a significant effect on $\mathrm{Q} / \mathrm{A}$ values for the 5-year recurrence interval. At the 100-year recurrence interval, permeability, channel slope, and mean annual precipitation did not have a significant effect on Q/A; however, time of concentration was a significant factor in determining Q/A for the 100-year events with greater times of concentration resulting in lower $\mathrm{Q} / \mathrm{A}$ values. Additional high-recurrence interval (5-, 10-, 25-, 50-, and 100-year) precipitation/discharge data are needed to confirm these relations suggested above. Discharge data with attendant basin-wide precipitation data from precipitation-radar estimates provides a unique opportunity to study the effects of basin characteristics on the relation between precipitation recurrence interval and discharge-recurrence interval.

Discharge-frequency values from the Q/A equations, the rational method, and the Kansas discharge-frequency equations (KFFE) were compared to 28 measured weatherradar precipitation-/discharge-frequency values. The association between precipitation frequency from weather-radar estimates and the frequency of the resulting discharge was shown in these comparisons. The measured and Q/A equation computed discharges displayed the best equality from low to high discharges of the three methods. Here the slope of the line was nearly $1: 1\left(\mathrm{y}=0.9844 \mathrm{x}^{0.9677}\right)$. Comparisons with the rational method produced a slope greater than $1: 1\left(\mathrm{y}=0.0722 \mathrm{x}^{1.235}\right)$, and the KFFE equations produced a slope less than $1: 1\left(\mathrm{y}=5.9103 \mathrm{x}^{0.7475}\right)$. The $\mathrm{Q} / \mathrm{A}$ equation standard error of prediction averaged $0.1346 \log$ units for the 5.4-to 32-square-mile group and $0.0944 \log$ units for the less than 5.4-square mile group. The KFFE standard error averaged $0.2107 \log$ units for the less-than-30-square-mile equations. Using the $\mathrm{Q} / \mathrm{A}$ equations for determining discharge frequency values for ungaged sites thus appears to be a good alternative to the other two methods because of this smaller error.

\section{Introduction}

There is a considerable need to refine discharge-frequency estimation for small basins in Kansas. Information concerning frequency of peak discharges in rural areas is vital to the cost-effective design of transportation drainage structures, such as bridges and culverts, and discharge-control structures, such as dam levees and floodways. Effective floodplain management programs and flood-insurance rates also are based on the analysis of discharge frequency. An investigation of discharge frequencies for small basins was conducted by the U.S. Geological Survey, in cooperation with the Kansas Department of Transportation to decrease the uncertainty 
of discharge-frequency estimates. Much of the data used in this study, especially for many of the stream-gaging stations located in small basins of less than $32 \mathrm{mi}^{2}$, were collected by the U.S. Geological Survey (http://nwis.waterdata.usgs.gov/ usa/nwis/peak) as part of a cooperative program initiated with the Kansas Department of Transportation in 1956.

\section{Purpose and Scope}

The primary purpose of this report is to decrease the uncertainty of discharge-frequency estimates for basins less than $32 \mathrm{mi}^{2}$. A secondary purpose is to describe precipitationfrequency and discharge-frequency relations by examining the possibility of using precipitation-recurrence interval to estimate the discharge-recurrence interval for ungaged sites. Normally, to estimate discharge frequency, a multiyear record of annual maximum discharge is needed, and to relate it to precipitation frequency, rainfall intensity for each annual maximum also is required. This information is not available; however, for this report, discharge measurements were made at sites that experienced high recurrence-interval precipitation events for which precipitation intensity was measured by weather radar. Discharge frequency refers to the probability that a discharge magnitude is equaled or exceeded. Recurrence interval refers to the return period on average between occurrences of a discharge magnitude.

An alternative analysis of discharge frequencies for unregulated, mostly rural streams at stream-gaging stations and at selected non-gaged sites is described. This analysis involved examining these streams using a ratio of discharge/ drainage area $(\mathrm{Q} / \mathrm{A})$ concept. Data from 128 basins with drainage areas less than $32 \mathrm{mi}^{2}$ with gaged information were used for this report. Additionally, 28 discharge measurements were collected at sites with basin area less than $32 \mathrm{mi}^{2}$ between August, 2003, and May, 2007, with precipitation depth and duration values from which precipitation-recurrence interval for each basin was estimated using time of concentration for each basin. Equations were generated for estimating discharge-frequency values for ungaged sites using the $\mathrm{Q} / \mathrm{A}$ data for gaged sites.

\section{Previous Studies and Data Collection}

A study of the magnitude of discharge frequencies was conducted by the U.S. Geological Survey on Kansas streams by Rasmussen and Perry (2000); discharges from 253 basins with drainage areas between 0.17 and $9,100 \mathrm{mi}^{2}$ were examined. Equations were developed for seven selected recurrence intervals ranging from 2 to 200 years (annual probability 0.5 to 0.005 , respectively). Regression equations were developed for two groups of discharge information: basins with areas between 30 and 9,100 $\mathrm{mi}^{2}$, and basins with areas less than $30 \mathrm{mi}^{2}$. This division resulted in an average standard error of prediction of $0.145 \mathrm{log}$ units for the larger basin group; however, the smaller basin group averaged $0.2107 \log$ units standard error. Predictive equations with lower standard errors of prediction are needed in determining discharge frequencies for small basins, especially for the larger recurrence intervals (25 to 200 years).

Discharge data collection for small basins in Kansas has been augmented by Crest-Stage Indicator (CSI) stream gages. CSI stream gages usually consist of a stationary wooden stick in a pipe that is supplied with cork at the lower end of the stick which, by adhering to the stick at the level of the crest of a discharge, provides the maximum stage of that discharge. These stream gages have a stage-discharge relation that has been developed from discharge measurements or by indirect measurement methods. The stage-discharge relation is site specific and needed to make estimates of annual maximum flows.

Collection of stage and discharge data for small basins is problematic in that the elapsed time between rainfall and peak discharge is small, typically only a few hours, and the direct measurement of discharge flow logistically difficult. Because of this, indirect measurements provide most of the discharge data. Indirect methods include slope-area, contracted-width, weir, and culvert hydraulic computations (Benson and Dalrymple, 1967). It may require many years of data collection before an adequate stage-discharge rating can be developed for a small basin; this may be mitigated by rating the stream gage site by numerical flow models, usually at culverts or bridges. Even then, it may be many years before a large discharge occurs at any one stream gage site. By one study, about 48 years of annual discharge records are needed to estimate the magnitude of a 100-year discharge event (0.01 annual probability) with a 25 percent error (Benson, 1952).

In an attempt to improve the discharge-frequency uncertainty for small basins in Kansas, Clement (1983) used short-term, 8 to 10 years, dual-digital rainfall-runoff data to synthesize long-term discharge information for 13 rural basins of less than $11 \mathrm{mi}^{2}$ in Kansas. The much longer synthesized discharge series (65 to 78 years) improved the Log Pearson III (LP3) analyses for each of the stream gaged stations.

An investigation was conducted (Rose and Hwang, 1985) to study flow differences between two sets of discharge-frequency curves developed for small rural basins of 7 to $35 \mathrm{mi}^{2}$ in Kentucky. One curve (discharge-based frequency curve) was derived directly from the annual series of discharge data, and the other curve (rainfall-based frequency curve) from the converted annual series of rainfall frequency data. The U. S. Water Resources Council LP3 frequency-distribution-fitting procedure was utilized for the determination of the dischargebased frequency curves. The U. S. Army Corps of Engineers, Discharge Hydrograph Package Computer Model (HEC-1) along with U. S. National Weather Service rainfall-frequency data (TP-40 and HYDRO-35) were used in the simulation of the basin rainfall-runoff process for the determination of the rainfall-based frequency curves. Generally, the flow magnitudes from the rainfall-based frequency curve were greater than those from streamflow-based frequency curves. 


\section{Methods of Computing Discharge Frequency Values}

Uncertainty in determining the discharge-frequency values for small streams in Kansas is decreased in this study by utilizing the discharge information for all stream-gaged information in a discharge-per-unit-area configuration. Dischargefrequency equations were developed from simple ranked distributions of stream-gaged discharge-per-unit-area $(\mathrm{Q} / \mathrm{A})$ data. These equations were then tested using precipitationrecurrence interval in place of discharge-recurrence interval.

\section{Rational Method}

One method that has been used extensively for small basins to estimate the t-year (recurrence interval) discharge is the rational method (Maidment, 1992). This method is expressed by the equation:

$$
\mathrm{Q}_{\mathrm{t}}=1.008 \mathrm{C} \mathrm{I}_{\mathrm{t}} \text { Tc A }
$$

where $Q_{t}$ is the discharge in cubic feet per second $\left(\mathrm{ft}^{3} / \mathrm{s}\right)$ for recurrence interval $t$ in years; $C$ is the runoff coefficient, which is dimensionless and is loosely defined as the ratio of runoff to rainfall; $\mathrm{I}$ is the rainfall intensity in inches per hour (in/hr) for recurrence interval $\mathrm{t}$; $\mathrm{Tc}$ is the time of concentration, in minutes, for the basin; and A is the area of the basin in square miles. The equation for $\mathrm{Tc}$ is:

$$
\mathrm{Tc}=21.3 \mathrm{~L} \mathrm{~A}^{-0.1} \mathrm{~S}^{-0.2}
$$

where $\mathrm{L}$ is the longest distance along the flow line from the basin divide to the point of discharge determination, in miles (mi); $\mathrm{A}$ is the area of the basin in $\mathrm{mi}^{2}$; and $\mathrm{S}$ is the average dimensionless channel slope (Williams, 1922).

The rational method is based on three assumptions: the peak runoff at any design location is a function of the average rainfall intensity during the time of concentration to that location; the recurrence interval of peak discharge is the same as the recurrence interval of the average rainfall intensity; and the time of concentration is the time required for water to flow from the most remote point of the area to the outlet. It is assumed that when the storm duration equals the time of concentration, all parts of the basin are contributing simultaneously to the discharge at the outlet. The rational method is recommended to be used on small rural basins of the order of $1.0 \mathrm{mi}^{2}$ or less (Ponce, 1989).

Though the rational method commonly is used on basins with less than $1.0 \mathrm{mi}^{2}$ (Hayes and Young, 2006), the rational method also has been used to estimate discharge values for larger basins of 1 to $10 \mathrm{mi}^{2}$ in Maine (Hodgkins and others, 2007). In this report, the rational method is used and compared with other methods for basins up to $32 \mathrm{mi}^{2}$.

\section{Kansas Discharge Frequency Equations}

Rasmussen and Perry (2000) used techniques from Bulletin 17B of the Interagency Advisory Committee on Water Data (1981) to estimate discharge frequency from 253 streamgaging stations with 10 or more years of unregulated, rural discharge record. Unregulated, rural basins are defined in Kansas as basins with less than 10 percent of the basin regulated by dams, or have less than 10 percent impervious land-use conditions. Of these 253 stations, 91 of the drainage areas were less than $30 \mathrm{mi}^{2}$, and 58 were less than $10 \mathrm{mi}^{2}$. LP3 distributions were fitted to the discharge data for each site. Adjustments then were made to account for data that represented low or high outliers, and for historical data where necessary. Final estimates of discharge frequencies at each stream-gaging station were computed using the generalized skewness coefficients obtained for each station (Hardison, 1974) as recommended in Interagency Advisory Committee on Water Data Bulletin 17B (1981).

Multiple linear regression analysis was used to relate the peak discharge at selected recurrence intervals to various physical and climatic characteristics. A generalized least squares (GLS) analysis (Tasker and Stedinger, 1989) was used to develop equations to determine discharges at specific recurrence intervals for ungaged sites on unregulated, rural streams. These equations took the form:

$$
\mathrm{Q}_{\mathrm{t}}=10^{\mathrm{a}} \mathrm{W}^{\mathrm{b}} \mathrm{X}^{\mathrm{c}} \mathrm{Y}^{\mathrm{d}} \mathrm{Z}^{\mathrm{e}}
$$

where $Q_{t}$ is the discharge for a specific recurrence interval; $\mathrm{a}, \mathrm{b}, \mathrm{c}, \mathrm{d}$, and e are exponents (derived from the regression coefficients); and W, X, Y, and Z are physical and climatological characteristics (explanatory variables). For basin areas between 30 and 9,100 $\mathrm{mi}^{2}$, the explanatory variables were contributing drainage area, mean annual precipitation for the basin, average soil permeability for the basin, and the slope of the main stream channel. For basins less than $30 \mathrm{mi}^{2}$, only contributing drainage area and mean annual precipitation were statistically significant.

\section{Discharge/Drainage Area Method}

Equation 1 can be rearranged into the form:

$$
\mathrm{Q}_{\mathrm{t}} / \mathrm{A}=1.008 \mathrm{C} \mathrm{I}_{\mathrm{t}} \mathrm{Tc}
$$

Employing the Q/A concept to the stream gaged-discharge data set has the advantage of increasing the discharge information data points that can be analyzed together. Discharge data from several stations with similar basin characteristics can be combined and analyzed as a single group. An added advantage is that individual station record length is not a constraining factor. Each year's peak flow divided by it's drainage area is an independent data point. Q/A can be examined in light of basin characteristics to standardize $\mathrm{C}$, as well 
as precipitation intensity characteristics, and subsequently, precipitation frequency.

\section{Precipitation Frequency and Intensity}

Precipitation records extend back to 1895 in Kansas, from which depth-duration probability tables have been computed and mapped (U.S. Weather Bureau, 1961). An updated analysis is provided for the Kansas City Metropolitan Area (Young and McEnroe, 2006). Stream basin characteristics, such as size, shape, soil permeability, stream slope, and antecedent moisture conditions, are some of the factors that must be considered when trying to relate precipitation depth-duration recurrence intervals to runoff recurrence interval estimates.

Precipitation amounts and intensities (hourly) for locations in Kansas have been published by the National Weather Service for many years (NOAA, 2007). A few of these stations are in near proximity (within a few miles) of a few of the stream-gaging stations. Precipitation data also currently (2007) are being collected by the U.S. Geological Survey at selected continuous stream-gaging stations. Most of these basins are larger than $30 \mathrm{mi}^{2}$ but may be in the proximity of smaller stream gaged basins. In addition, when some of the CSI stream gages were installed in 1957, they were equipped with dual-digital punch recorders (data loggers) that collect stage and precipitation data. This precipitation intensity and duration data can be used to determine the precipitation-recurrence interval that corresponded to measured discharge events.

\section{Discharge/Area (0/A) Analyses}

Discharge-frequency analyses for basins less than $32 \mathrm{mi}^{2}$ were conducted on two primary data sets. The first set consisted of all the discharge information gathered from 128 stream gages on small unregulated rural streams in Kansas. Some of the greater-than-10-year recurrence interval events had anecdotal rainfall information (usually daily), but the primary analysis was in the form of the conventional frequency analyses of the peak discharge for each site (Bulletin 17B: Interagency Advisory Committee on Water Data, 1981), and then developing regional regression equations. In this study, all the discharge values were divided by the drainage area of each basin, and frequency analyses were conducted on the combined group. For drainage basins less than $32 \mathrm{mi}^{2}$, the data set included 3,103 individual discharge/drainage area (Q/A)values.

The second data set consisted of discharge values for ungaged streams for which the precipitation intensity was available from weather radar estimates, or from nearby recording raingages; therefore, precipitation-recurrence intervals could be determined. Instead of waiting for extreme precipitation-intensity events to occur for basins that have been gaged for discharge information, the region of the radar-documented precipitation event was examined for extreme runoff events, and then indirect methods of discharge determination were used to obtain a discharge magnitude. The recurrence interval of the rainfall event was then used to estimate the runoff recurrence interval.

\section{Existing Stream-Gage Information}

Discharge data from all stream-gaging stations in Kansas with areas less than $32 \mathrm{mi}^{2}$ were examined in this study (fig. 1). Each year's peak discharge, divided by basin area, was assumed to be an independent, unrelated event that is assumed to be statistically independent from year to year and station to station. There were 128 basins with a total of 3,103 peak-flow events for basins less than $32 \mathrm{mi}^{2}$. This group was subdivided into a subgroup of basins less than $5.4 \mathrm{mi}^{2}$. The value of $5.4 \mathrm{mi}^{2}$ was very close to the median for all basins less than $32 \mathrm{mi}^{2}$. It was also a logical break as the next largest basin size in the complete data set was $6.57 \mathrm{mi}^{2}$. The subgroup of less than $5.4 \mathrm{mi}^{2}$ consisted of 60 basins and 1,620 Q/A values. The basin and climatic characteristics, including soil permeability, channel slope, and mean annual precipitation, were compiled for each Q/A value. These basin and climatic factors are common predictors in discharge equations in the Midwest (Jennings and others, 1994). The stream-gaging stations and corresponding basin characteristics are listed in table 1. Basin characteristics were obtained through the Kansas Stream Statistics web page: http://ks.water.usgs.gov/Kansas/studies, strmstats). The two primary groups, basins less than 32 but greater than $5.4 \mathrm{mi}^{2}$, and basins less than $5.4 \mathrm{mi}^{2}$, were divided according to quartiles for each of the basin characteristics (permeability, slope, and mean annual precipitation) and frequency plots were constructed for each quartile and for each basin characteristic. Two methods for estimating the frequency of each quartile were used. First, a simple ranked frequency plot (where the frequency is determined by rank number divided by $\mathrm{n}+1$ ), and second, a LP3 distribution was fit to the product moments.

The ranked frequency plots for the stream gaged data are shown in figure 2 for basins less than $5.4 \mathrm{mi}^{2}$, and for basins between 5.4 and $32 \mathrm{mi}^{2}$. Each basin characteristic was divided into quartiles. The plots for permeability (figs. $2 A$ and $2 D$ ) show the expected relation with $\mathrm{Q} / \mathrm{A}$ in which basins with less permeable soils have greater Q/A. The plots of Q/A for channel slopes (figs. $2 B$ and $2 E$ ) vary somewhat from the expected increase in $\mathrm{Q} / \mathrm{A}$ with increasing slope. There were variations from the intuitive progression of greater $\mathrm{Q} / \mathrm{A}$ for greater slopes. Mean annual precipitation followed the expected progression for both groups (figs. $2 C$ and $2 F$ ) with basins having lower mean annual precipitation also having lower Q/A values. Variations from expected relations may be a result of small sample sizes.

A LP3 frequency analysis of Q/A was performed on the data using a variation of the Bulletin 17B (Interagency Advisory Committee on Water Data, 1981) computer program 


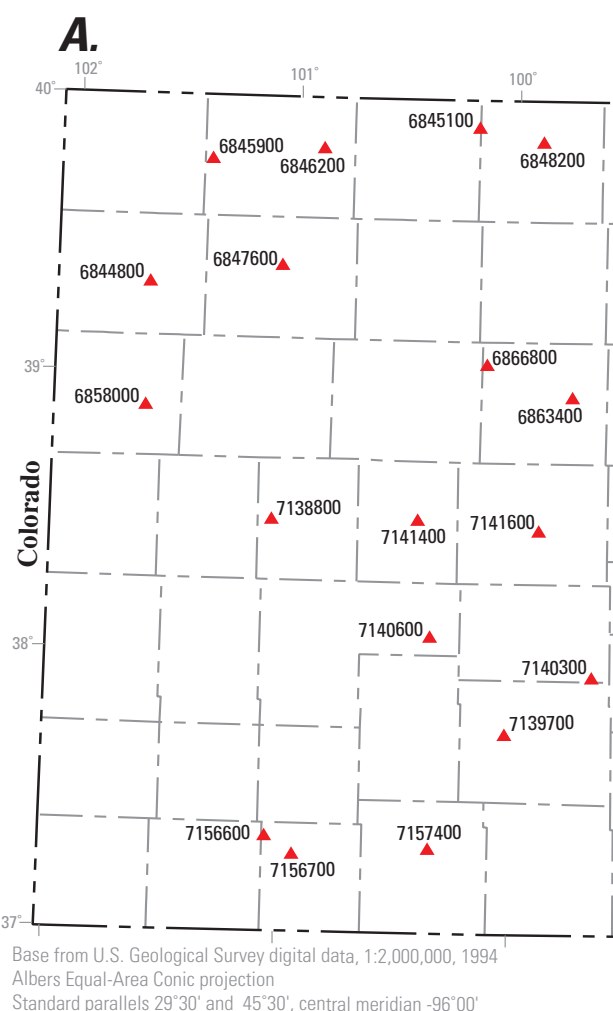

\section{EXPLANATION}

\section{0 _U.S. Geological Survey peak-discharge stream-gaging station and number (See map above and table 1)}

12 Precipitation/discharge site and number (See map on right and table 2)

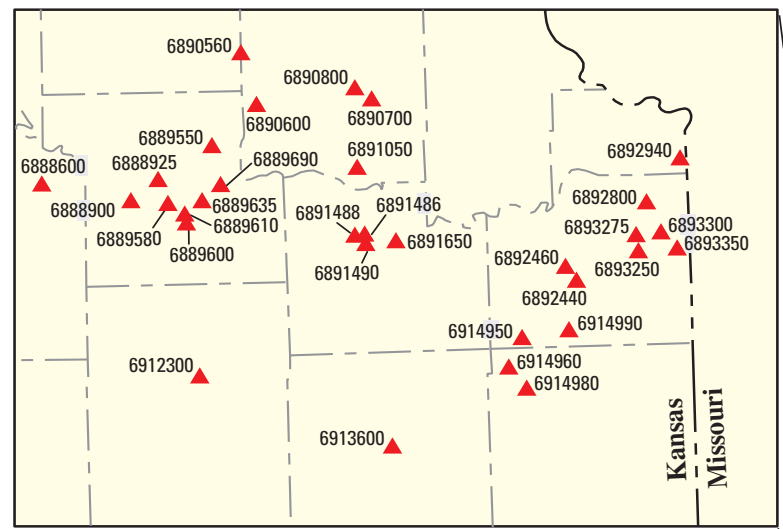

Enlarged area 


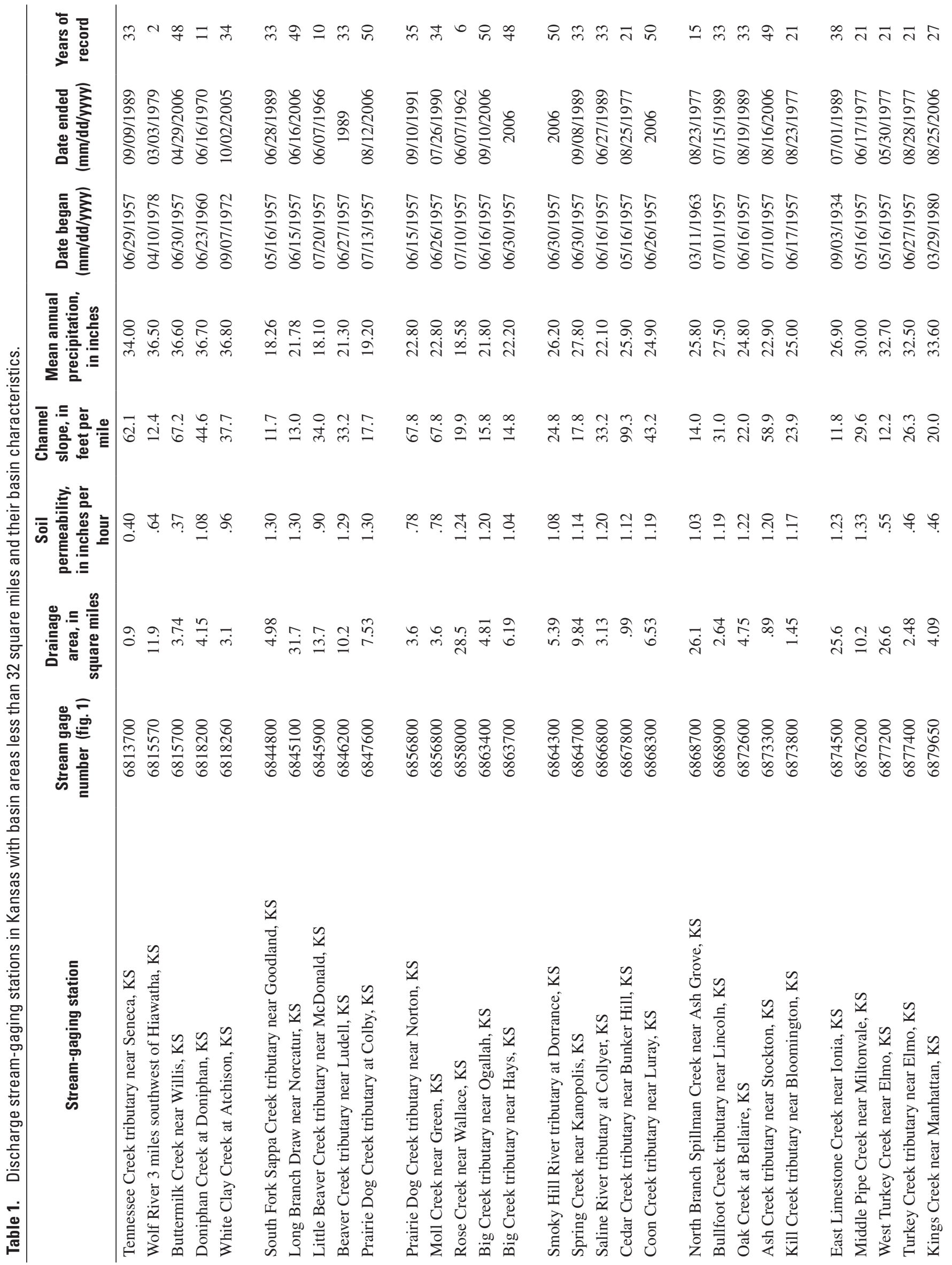




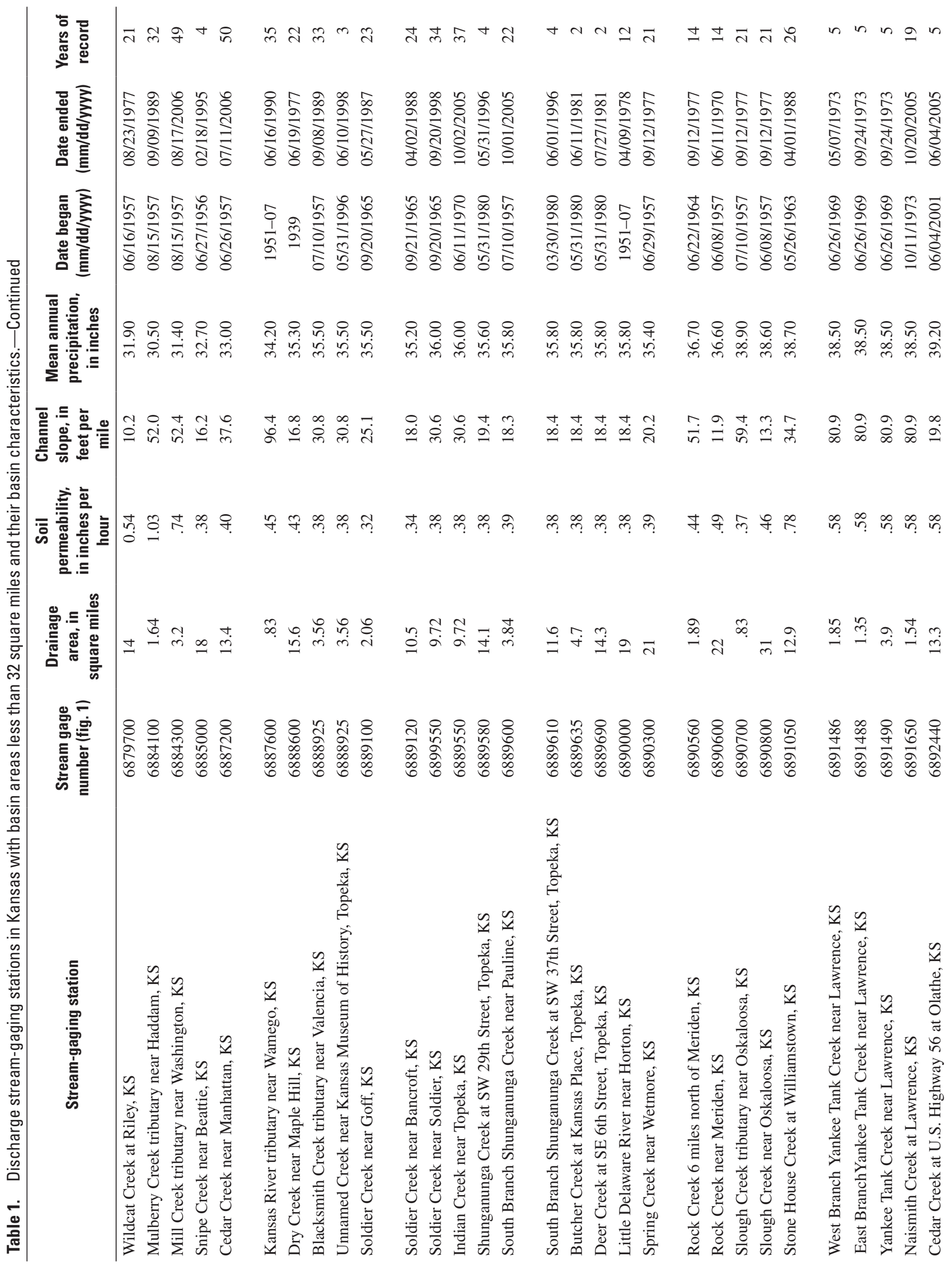




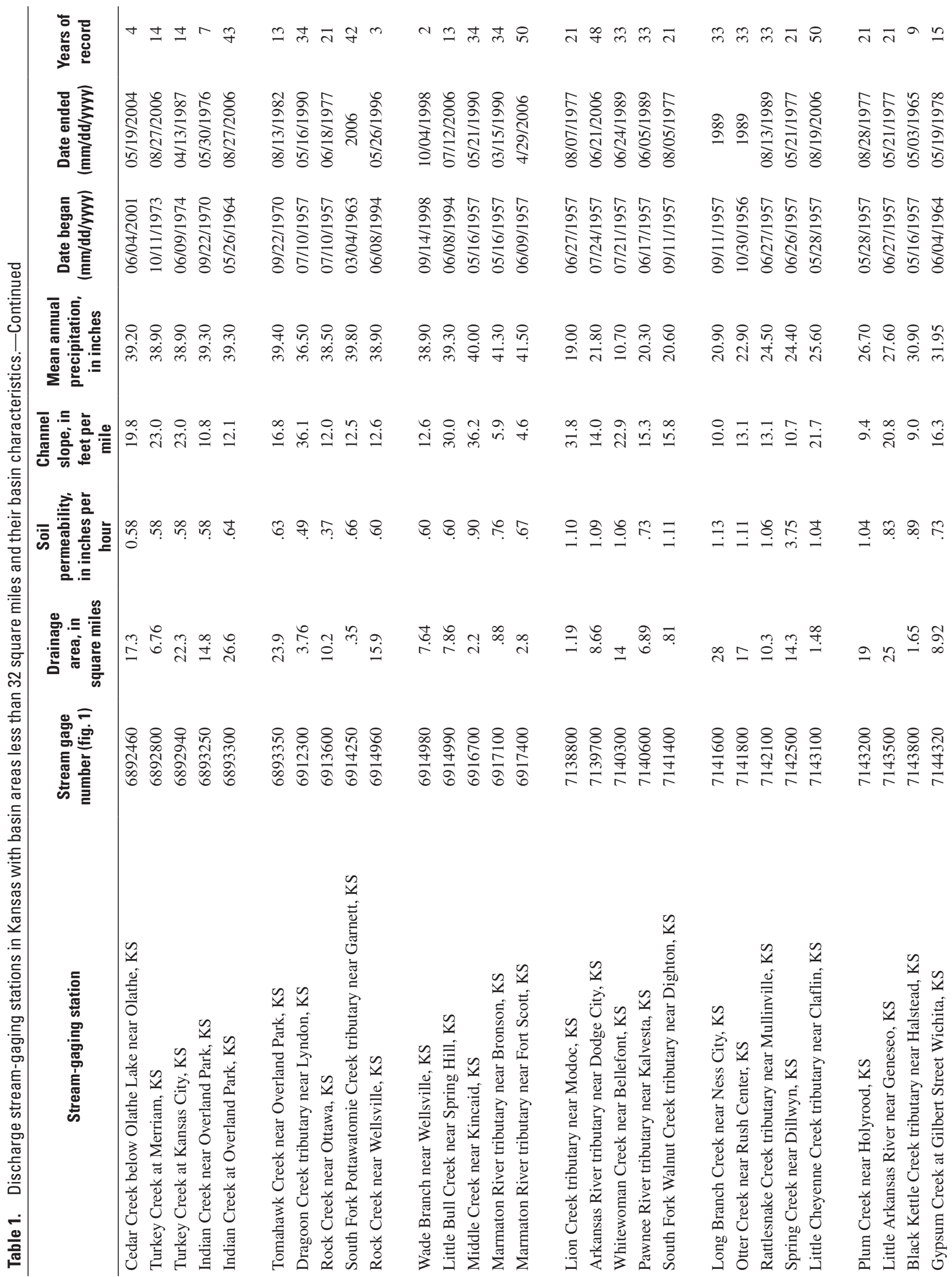




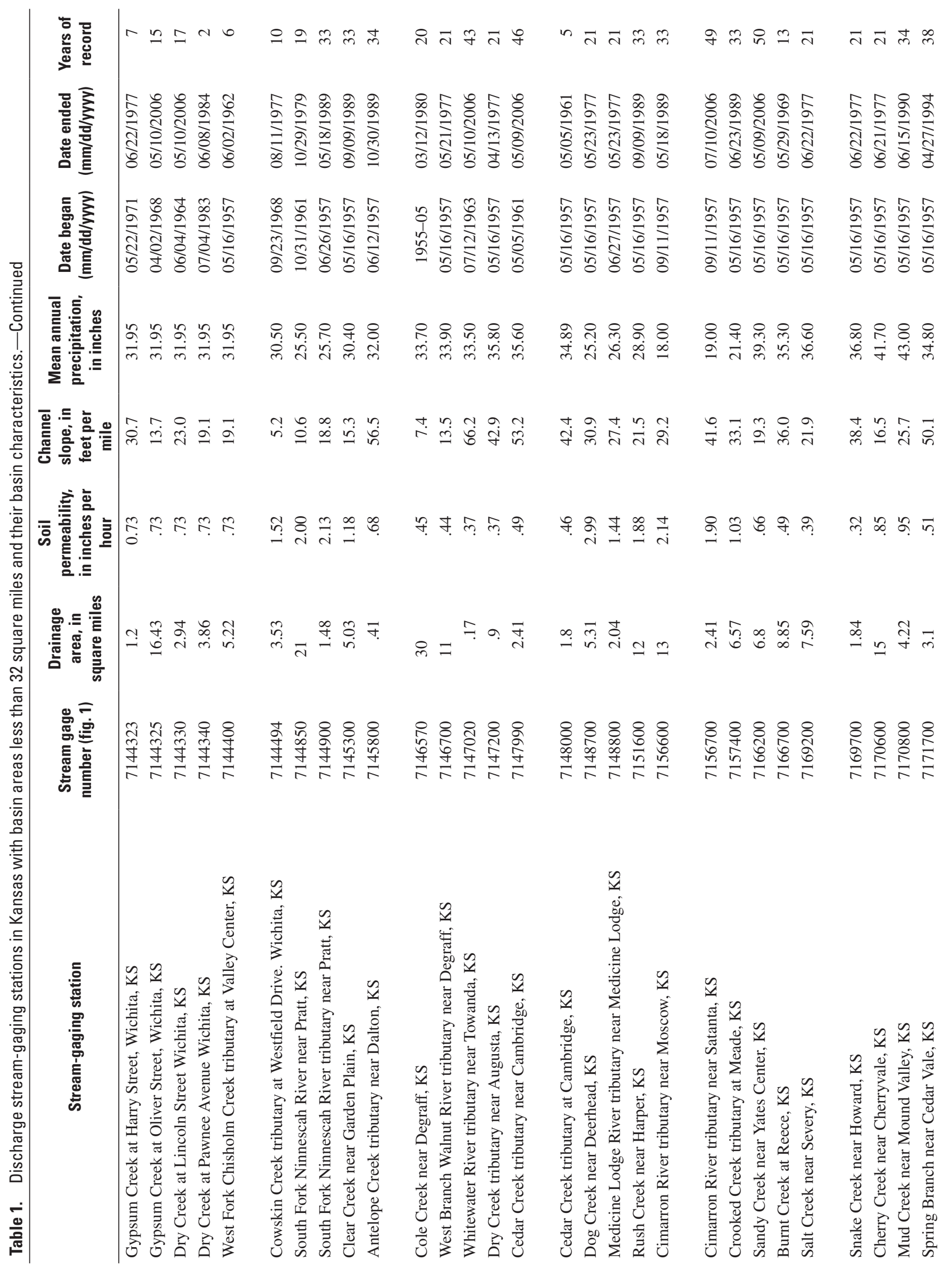




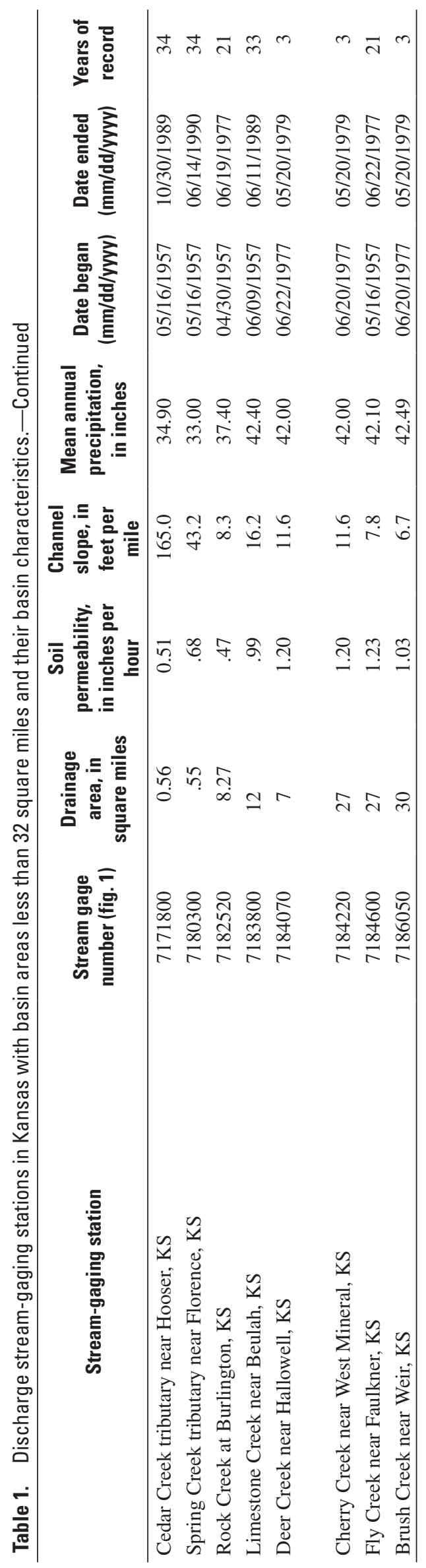


(A) Quartiles of permeability for basins less than 5.4 square miles

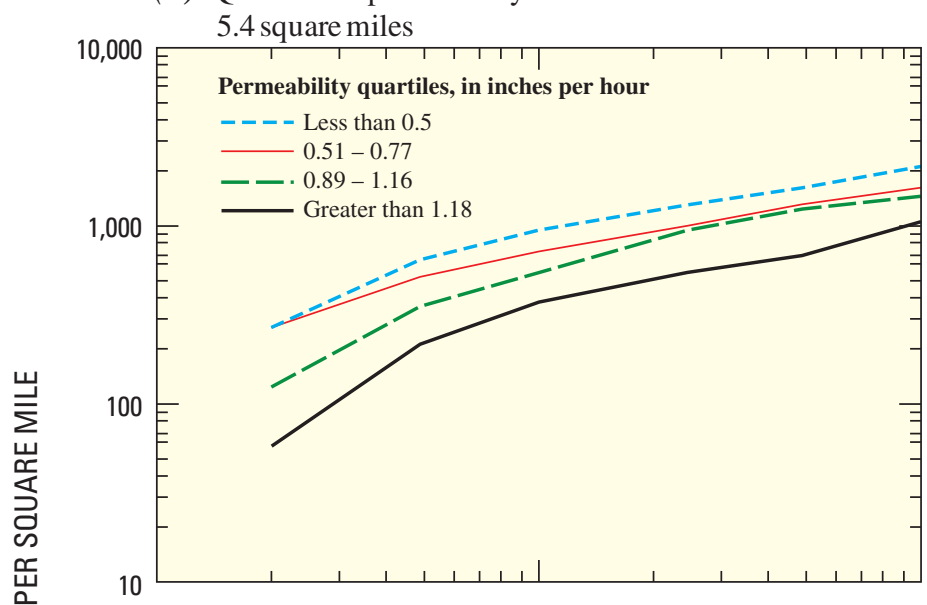

(B) Quartiles of slope of channel for basins less than 5.4 square miles

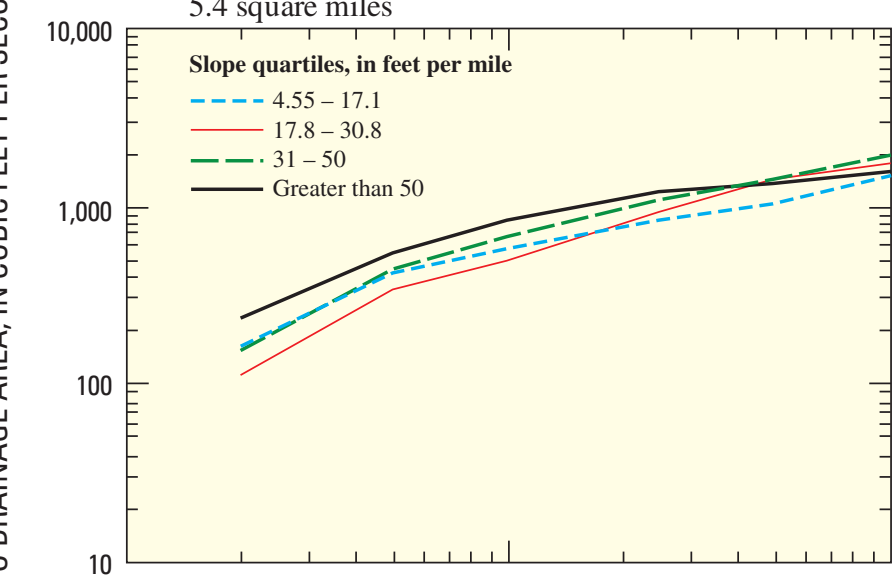

(C) Quartiles of annual precipitation for basins less than 5.4 square miles

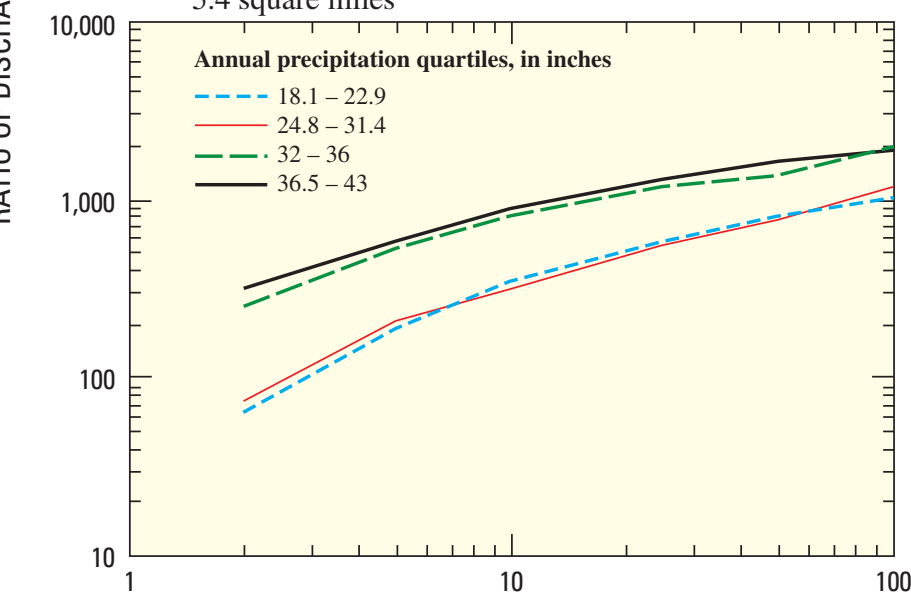

(D) Quartiles of permeability for basins 5.4 to 32 square miles

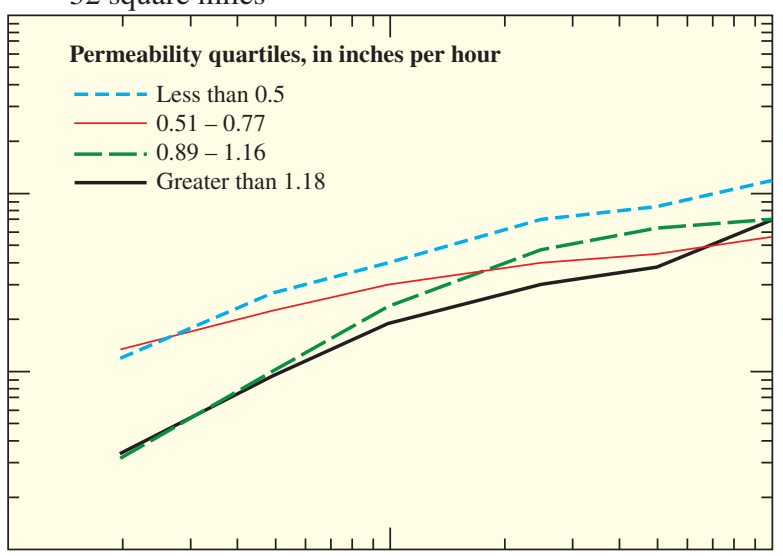

(E) Quartiles of slope of channel for basins 5.4 to 32 square miles

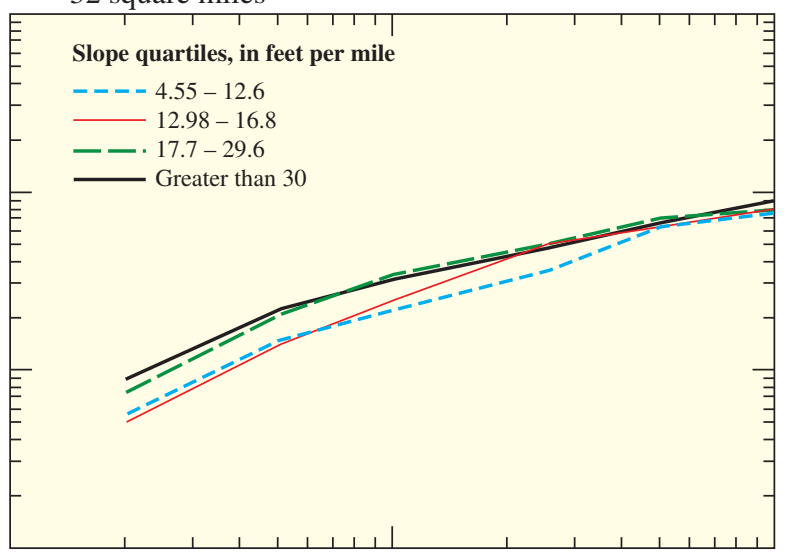

(F) Quartiles of annual precipitation for basins 5.4 to 32 square miles

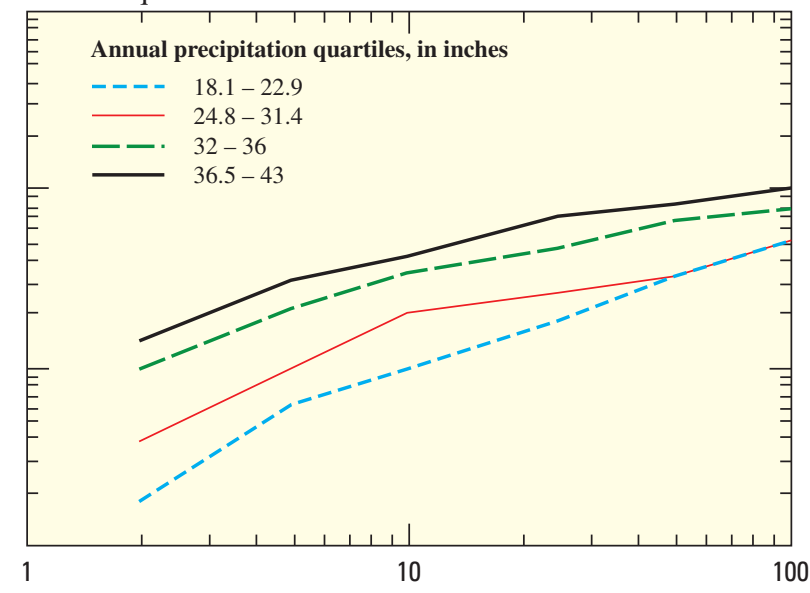

Figure 2. Simple ranked frequency distribution of discharge/drainage area $(\mathrm{Q} / \mathrm{A})$ for gaged data, for the various quartiles of permeability $(A, D)$, channel slope $(B, E)$, and mean annual precipitation $(C, F)$ for basins of 5.4 to 32 square miles $(A, B, C)$, and basins of 0.17 to 5.4 square miles $(D, E, F)$. 
that analyzed up to 4,000 Q/A values (T.A. Cohn, USGS, written commun., 2007). Initially, three groups of the entire data set were examined. The three groups of data were: all basins less than $32 \mathrm{mi}^{2}$; basins less than $5.4 \mathrm{mi}^{2}$; and basins between 5.4 and $32 \mathrm{mi}^{2}$. A skewness coefficient of -0.9 (the value of all Q/A data less than $32 \mathrm{mi}^{2}$ ) was used for all four groups for consistency. The frequency plots for these analyses are shown in figure 3. This figure shows that as basin size gets smaller the Q/A generally becomes larger.

The data groups of less than $5.4 \mathrm{mi}^{2}$, between 5.4 and $32 \mathrm{mi}^{2}$, and all less than $32 \mathrm{mi}^{2}$ were examined alternatively using the 1 st , the 2 nd through the $3 \mathrm{rd}$, and 4 th quartiles for each of the three basin characteristics soil permeability, channel slope, and mean annual precipitation. The 2 nd and the 3rd quartiles were combined to present a central tendency, whereas the 1st and 4th quartiles provided a sense of range for the basin characteristics. For basins less than $5.4 \mathrm{mi}^{2}$ the skewness coefficient for $\mathrm{Q} / \mathrm{A}$ was -1.1; for basins between 5.4 and $32 \mathrm{mi}^{2},-0.9$; and for all basins less than $32 \mathrm{mi}^{2}$, the skewness coefficient was -0.9. The skewness coefficient for each quartile group was held constant for each basin area range. Plots of the discharge-frequency curves for basins less than $5.4 \mathrm{mi}^{2}$ are shown in figure $4 A-C$; for basins 5.4 to $32 \mathrm{mi}^{2}$, they are shown figure $5 A-C$. As in the simple ranked frequency analyses, permeability and precipitation generally followed the expected patterns in $\mathrm{Q} / \mathrm{A}$ and frequency, whereas the slope curves deviated from the expected relation.

\section{Precipitation-/Discharge-Site Information}

The relation between peak runoff events and precipitation rates and depths in Kansas was examined for the 1960s and early 1970s. The stream gages used in the rainfall/runoff determinations recorded precipitation and stream gage height data at 15-minute intervals. A product of this effort was discharge-frequency estimates for small basins from a long-

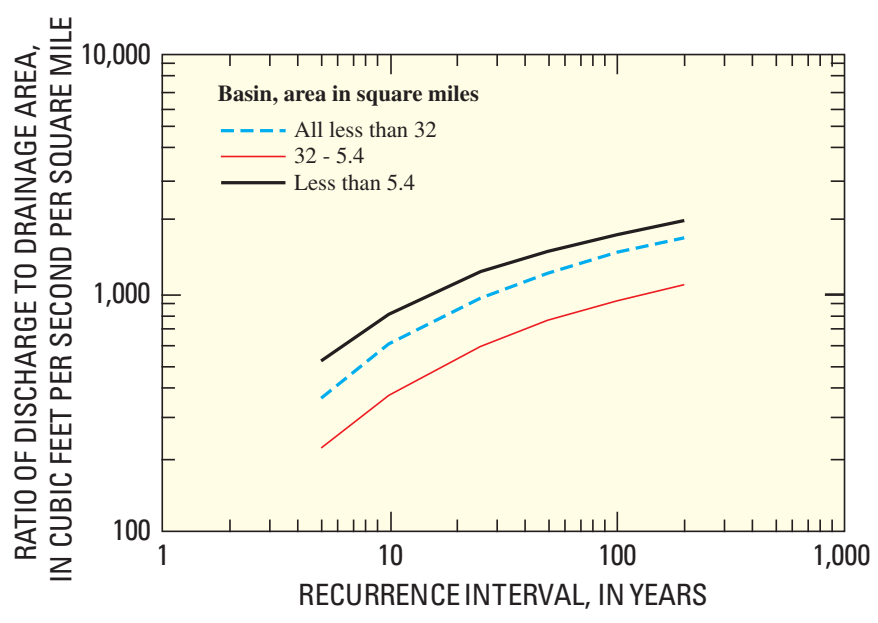

Figure 3. Log Pearson III frequency distribution (skew=-0.9) for discharge/drainage area ( $0 / A)$ for gaged data for all basins less than 32 square miles, less than 5.4 square miles, and for 5.4 to 32 square miles. term synthesis of peak flows using a rainfall/runoff model and a long-term precipitation record (Clement, 1983). This effort applied the discharge-based discharge-frequency analysis, but did not incorporate precipitation frequency estimates.

\section{Precipitation}

One of the problems of relating discharge-recurrence interval to precipitation-recurrence interval in the past was determining the rainfall depth for the basin in question, and having the ability to monitor that precipitation data in 10- to 15-minute intervals to obtain intensity. The National Weather Service maintains a network of recording and non-recording raingages throughout the State of Kansas (NOAA, 2007). However, most of these stream gages are tens of miles apart. Various analysis methods have been used to estimate basin rainfall depths such as a simple average, Thiessen Polygon Method (Thiessen, 1911), or graphical contouring methods (Linsley and others, 1958).

The development of the weather radar method of estimating rainfall depth has provided not only radially gridded rainfall depths, but these values also can be accumulated for various time scales to determine the duration and intensity of the rainfall (Serafin and Wilson, 2000). The radar-estimated precipitation depths and corresponding durations, when combined with precipitation-frequency charts, should allow for better rainfall/discharge frequency relations.

A pilot project, conducted by the U.S. Geological Survey in cooperation with the Kansas Department of Transportation in eastern Kansas (fig. $1 B$ ), to compare radar estimated rainfall depth/duration with discharge was begun in 2004 and, as a result of persistent drought conditions, extended to the summer of 2007. Radar maps of precipitation in inches per hour (obtained on a frequency of approximately every 10 minutes) were obtained through the Internet: http://radar.weather.govd radar.php? rid =twx\&product $=N O R \&$ overlay $=11101111 \&$ loop End) from the Topeka, Kansas National Weather Service radar precipitation map (fig. 6) and were examined for high-intensity precipitation events. Once an area was determined to have a significant (greater than 2-year) rainfall event, a field inspection of the area was conducted to find locations along affected streams where indirect methods of determining the discharge could be conducted.

\section{Discharge}

Once a site was chosen, a survey of high water marks, channel cross sections, and bridge or culvert dimensions, as well as an estimation of roughness coefficients for the channel and overflow sections were made and a discharge analysis was conducted. Most of the indirect surveys were conducted using a Global Positioning System (GPS) total station. Estimates of peak discharges were computed according to methods outlined by Benson and Dalrymple (1967). These methods include computation of discharge at dams (flow over a road) 
(A) Permeability for basins less than 5.4 square miles

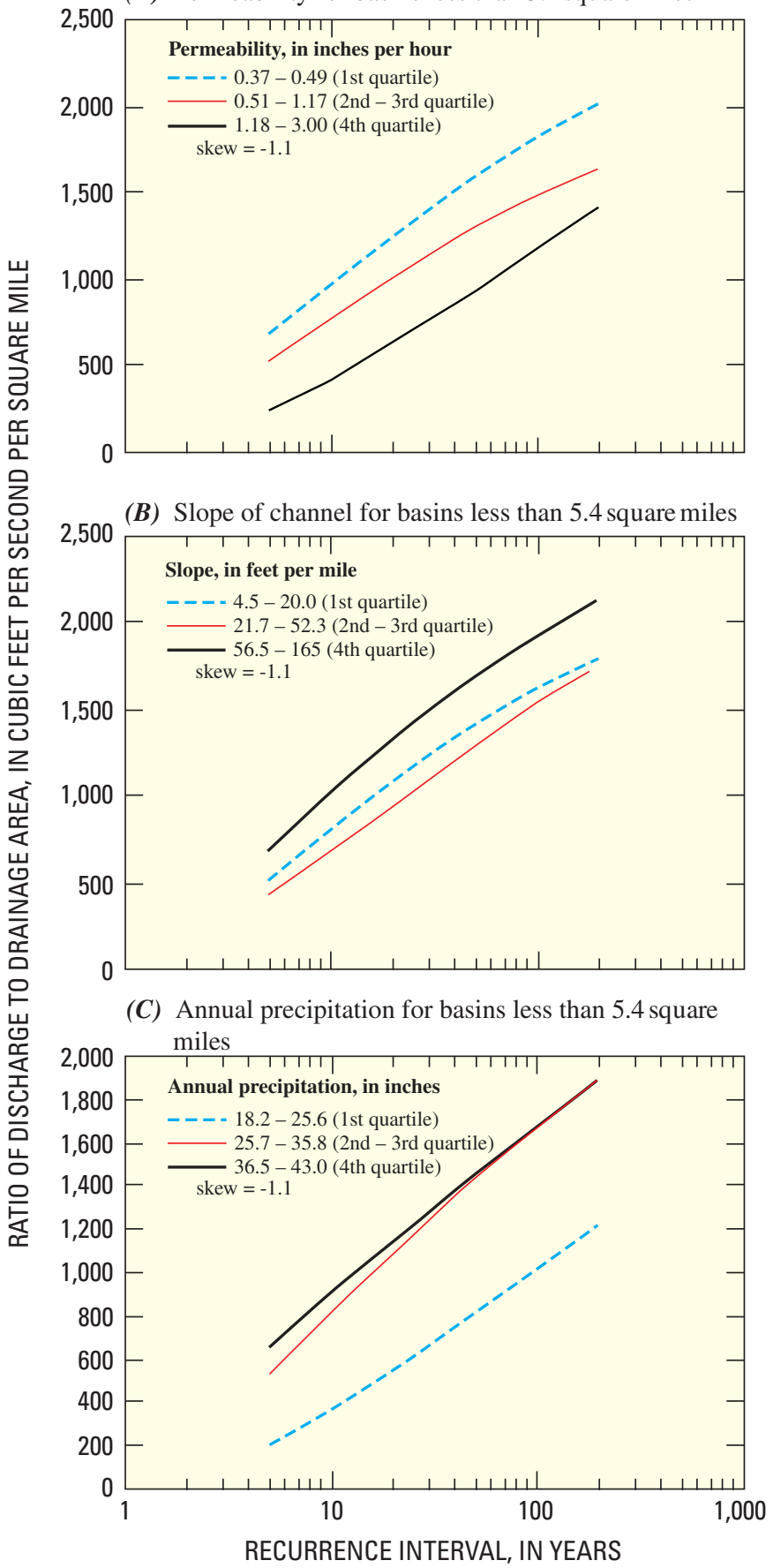

Figure 4. Log Pearson III frequency distribution (skew=-1.1) for discharge/drainage area $(\mathrm{Q} / \mathrm{A})$ for gaged data by $1 \mathrm{st}, 2 \mathrm{nd}$ through $3 r d$, and 4th quartiles of $(A)$ permeability, $(B)$ channel slope, and $(C)$ mean annual precipitation, for basins less than 5.4 square miles.
(A) Permeability for basins 5.4 to 32 square miles

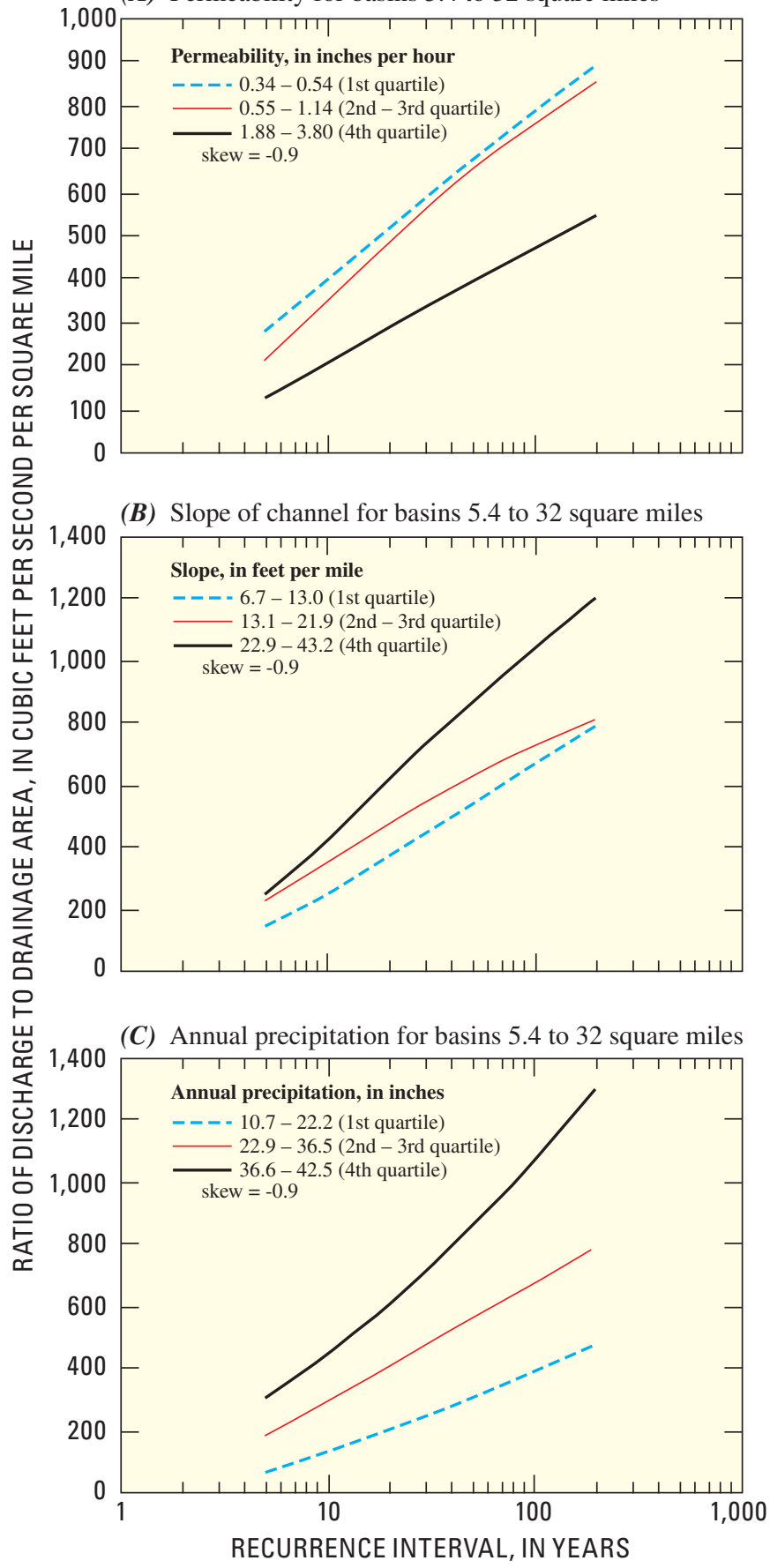

Figure 5. Log Pearson III frequency distribution (skew=-0.9) for discharge/drainage area $(\mathrm{O} / \mathrm{A})$ for gaged data by $1 \mathrm{st}, 2 \mathrm{nd}$ through $3 r d$, and 4 th quartiles of $(A)$ permeability, $(B)$ channel slope, and $(C)$ mean annual precipitation for basins 5.4 to 32 square miles. 


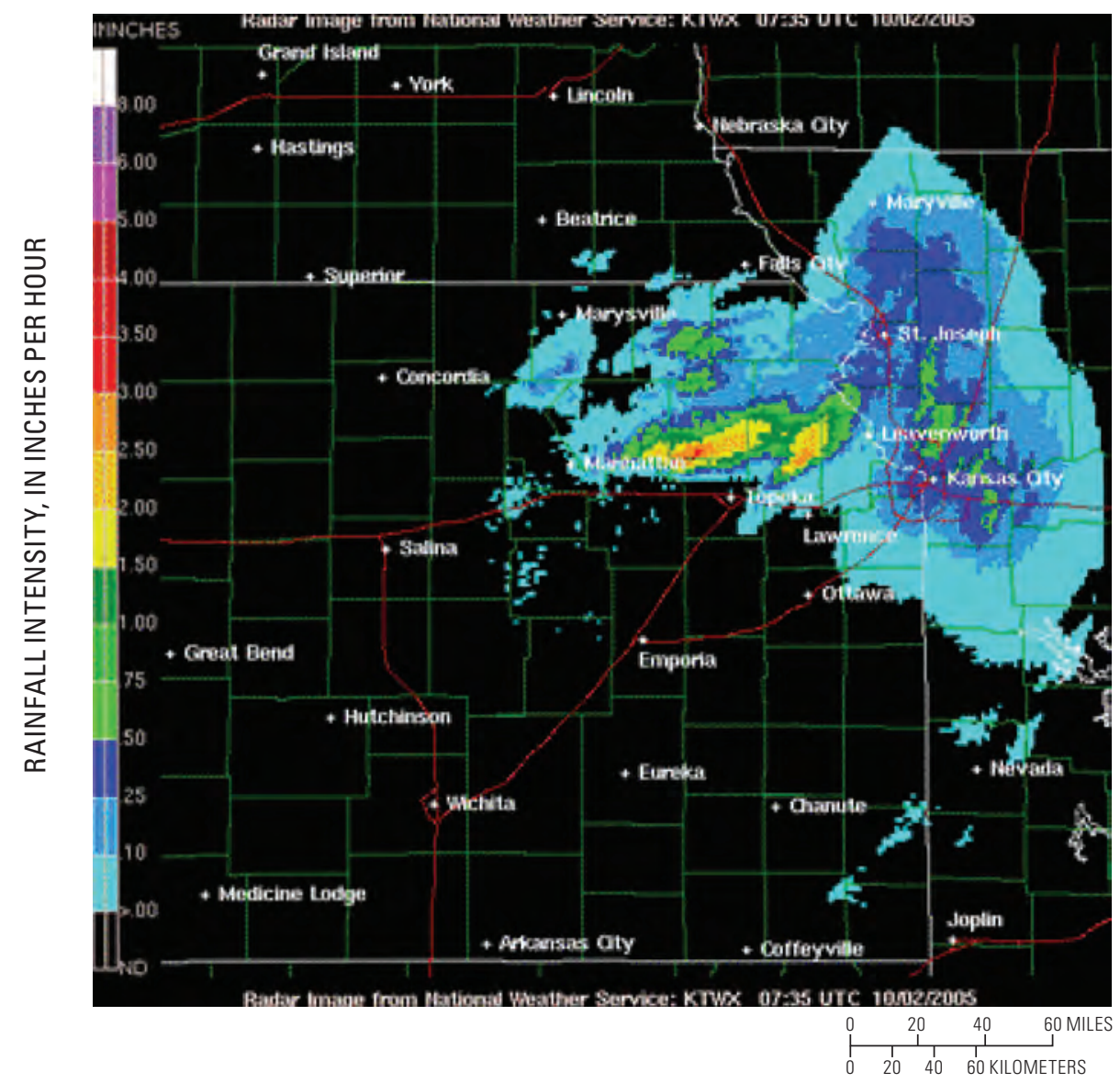

Figure 6. Example of 1-hour precipitation rate estimates from the Topeka, Kansas Weather Radar, (07:35 UTC, 02/10/2005).

(Hulsing, 1967), discharge at culverts (Bodhaine, 1968), discharge at contracted openings such as bridges (Matthai, 1967), and discharge by the slope-area method (Dalrymple and Benson, 1968). The indirect computations were performed using the HEC-RAS model (U.S. Army Corps of Engineers, 2006).

\section{Supplemental Stream Gage Data}

Precipitation/discharge frequency comparisons were not limited to measurements only by indirect methods. Peak discharge estimates also were provided by stage-discharge relations at existing stream gage sites, or were measured directly. Precipitation depth and duration also were obtained from nearby recording raingages.

\section{Precipitation/Discharge Sites}

Twenty-eight precipitation/discharge events were tabulated from August 2003 to May 2007 using radar-precipitation estimates and recording raingage data. These events are listed in table 2. Basin areas for these sites ranged from 0.72 to $31 \mathrm{mi}^{2}$.

\section{Precipitation-Recurrence Interval Determination}

The recurrence interval of the precipitation event for each discharge event was determined by first calculating the time of concentration for each basin. Time of concentration (equation 2) is determined from basin area (A), slope of the channel (S), and the distance (L) along the channel from the farthest divide to the point of determination of discharge (Williams, 1922). Using the time of concentration as the criteria to determine the maximum precipitation amount, a precipitation total was summed from individual radar total precipitation maps. That maximum precipitation amount per time of concentration was compared with the range of rainfall frequency amounts for each site (U.S. Weather Bureau, 1961; Young and McEnroe, 2006). The precipitation frequency analysis by Young and McEnroe (2006), which was for the Kansas City Metropolitan area, provided similar results as the previous U.S. Weather Bureau (1961) analyses for that area so the comparison of data collected for this report to values in U.S. Weather Bureau (1961) is appropriate.

Once the time of concentration was computed for a particular basin, an estimate of the maximum precipitation depth was obtained from weather radar, or nearby raingages. The total rainfall depth for the time of concentration results 


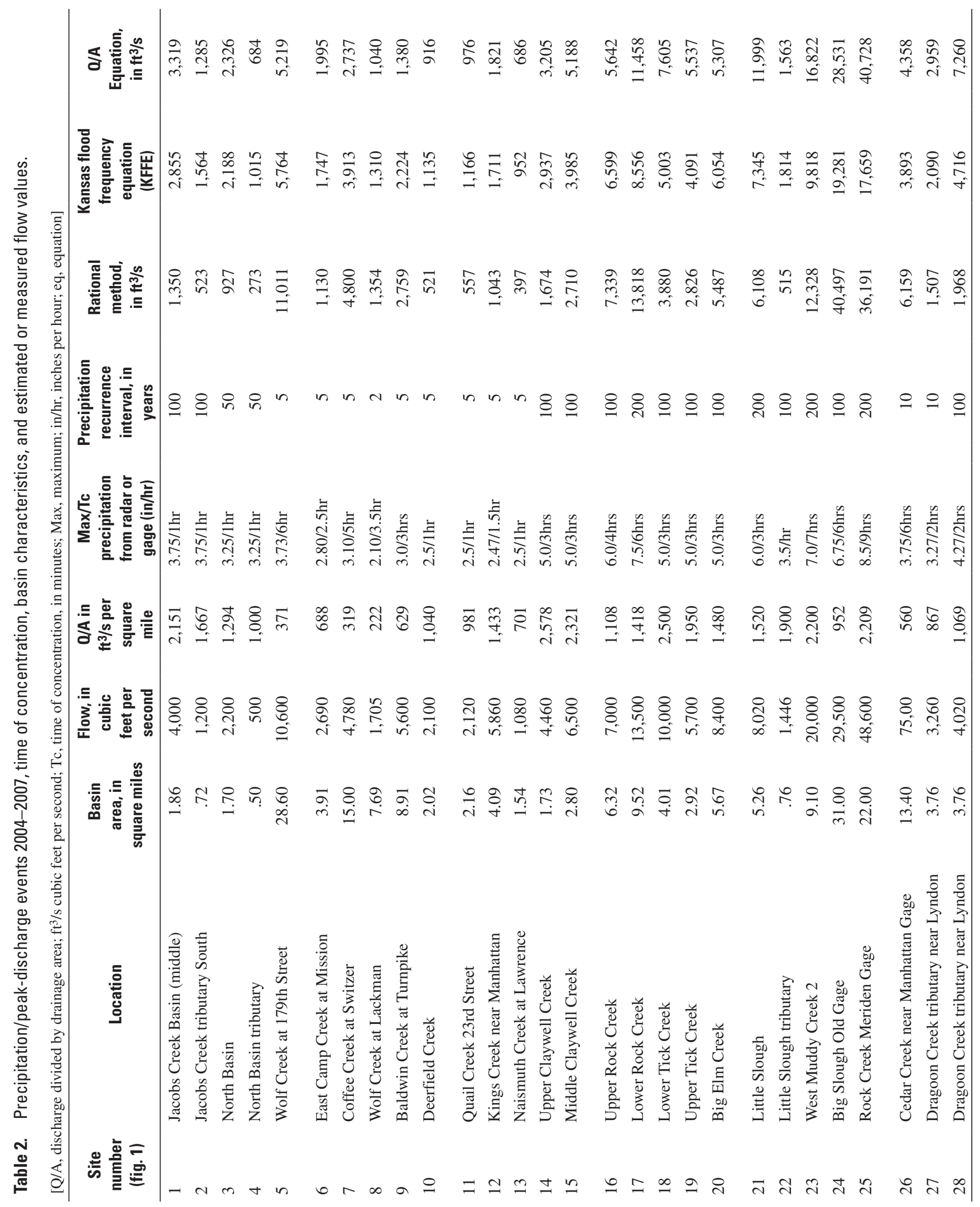


in an intensity. Weather radar precipitation estimates for 1-hour (fig. 6) and 3-hour (fig. 7) increments were used to estimate the maximum rainfall depth for that basin's time of concentration. Detailed precipitation maps with stream basins overlaid were supplied by the National Weather Service office in Topeka, Kansas (George Phillips, written commun., 2007). The mean rainfall intensity was determined for each basin with a measurement by area averaging for each storm. Raingages operated by the U.S. Geological Survey or the National Weather Service also were used in some cases to augment the radar-rainfall intensity. Precipitation frequency charts (U.S. Weather Bureau, 1961; Young and McEnroe, 2006) were used to estimate the precipitation recurrence interval for each event. This recurrence interval was assumed to be the recurrence interval of the discharge event. An example of a precipitation frequency plot for the Kansas City Metropolitan area (Young and McEnroe, 2006) is shown in figure 8. The recurrence intervals obtained for the 28 sites listed in table 2 ranged from 2 to 200 years. The time of concentration, which ranged from approximately 1 to 9 hours, basin characteristics, estimated discharges, and precipitation recurrence intervals also are listed in table 2.

Precipitation recurrence interval and discharge per unit area $(\mathrm{Q} / \mathrm{A})$ for all 28 of the events in table 2 were plotted in figure $9 A$. The relation resulted in a correlation coefficient of 0.79 . Using basins less than $5.4 \mathrm{mi}^{2}$ only the correlation decreases to 0.74 (fig. 9B). However, when basins greater than 5.4 and less than $32 \mathrm{mi}^{2}$ are examined the relation improves to a correlation coefficient of 0.95 (fig. 9C). Most of the unexplained variability may come from the basins that are less than $5.4 \mathrm{mi}^{2}$. This variability may be a function of other basin characteristics that vary considerably in the smaller basins.

\section{Precipitation-/Discharge-Frequency Distributions}

The general Q/A frequency curves obtained from the stream-gaged data (LP3) are compared with the precipitation recurrence interval and discharge per unit area data for basins

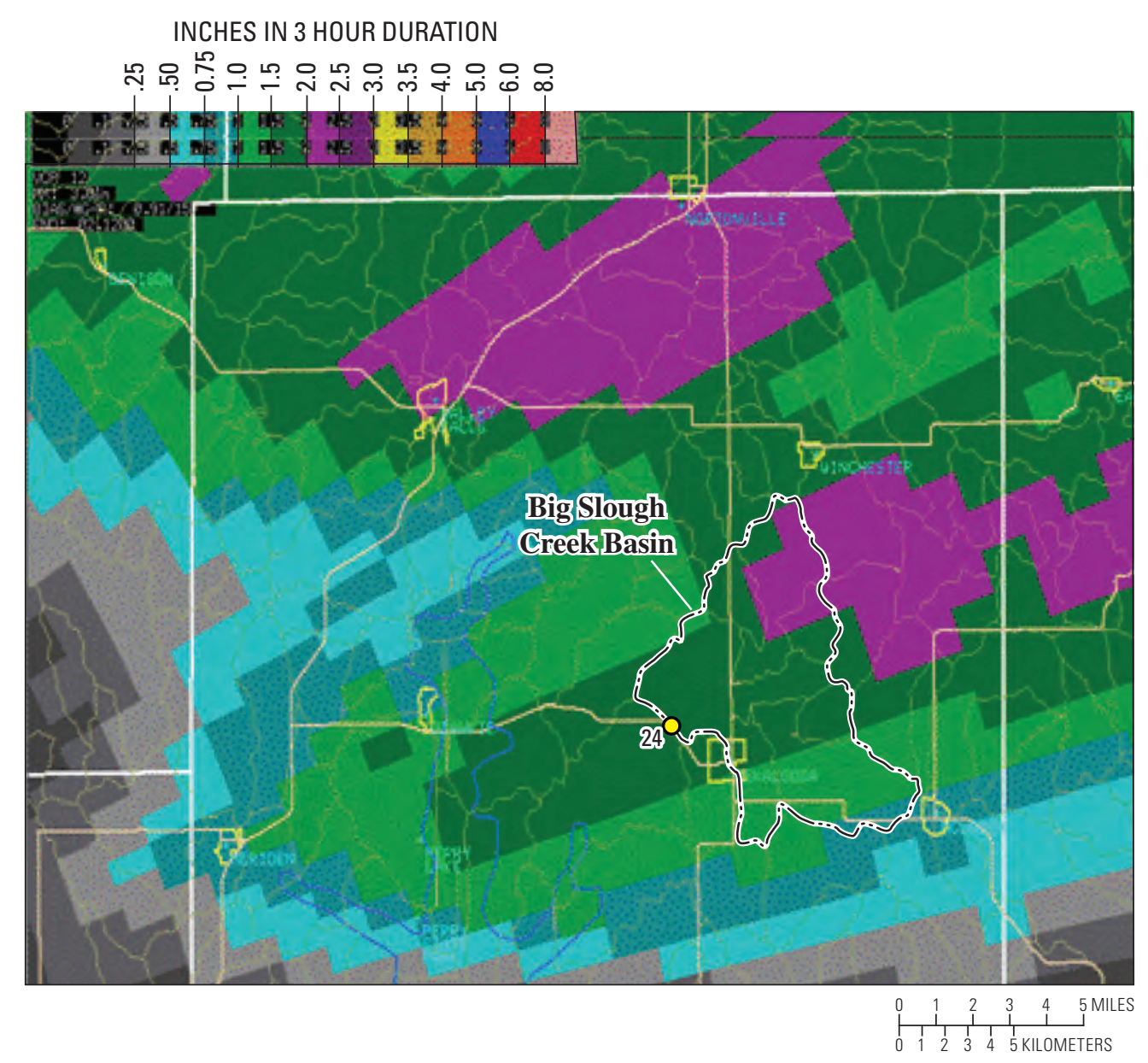

EXPLANATION

240 Precipitation/flood measurement location and number

Figure 7. Example of 3-hour precipitation estimates from the Topeka, Kansas Weather Radar, with superimposed basins, (12:12 UTC, 02/10/2005). 


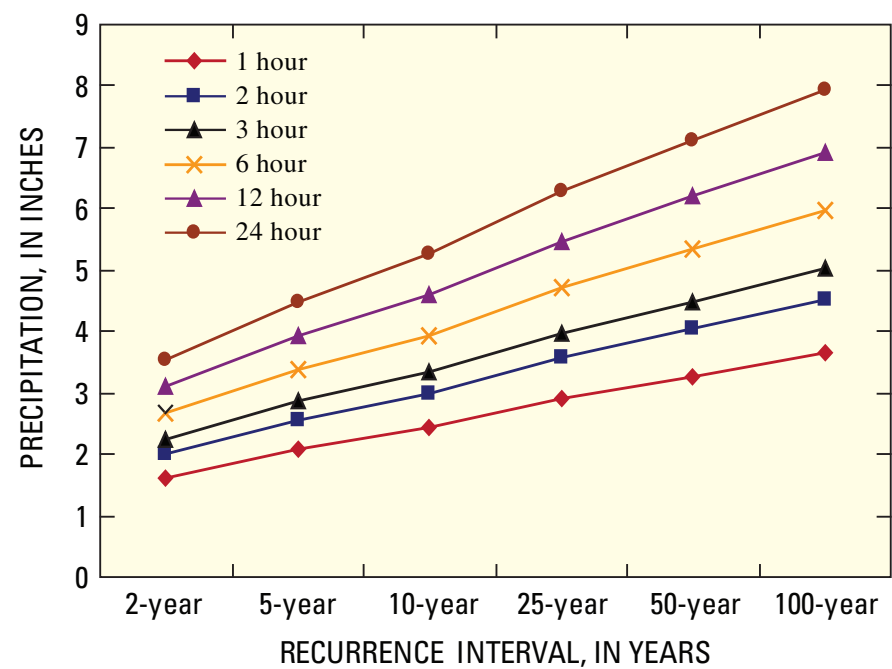

Figure 8. Precipitation-recurrence intervals for the Kansas City metropolitan area (modified from Young and McEnroe, 2006).

less than $5.4 \mathrm{mi}^{2}$ (fig. 10A), and for basins greater than 5.4 and less than $32 \mathrm{mi}^{2}$ (fig.10B). The comparisons for basins less than $5.4 \mathrm{mi}^{2}$ generally indicate that the $\mathrm{Q} / \mathrm{A}$ precipitation/discharge measurement curve is similar to the LP3 curve, diverging at the lower recurrence intervals with the LP3 providing lower values of $\mathrm{Q} / \mathrm{A}$. The comparison for basins greater than 5.4 and less than $32 \mathrm{mi}^{2}$ indicates that the LP3 curve consistently is lower than the measurement curve. This could be interpreted as the measured values being consistently higher than the stream gaged data, or that the precipitation/discharge frequency estimates of recurrence interval were too low.

For all 28 events, there were multiple data points for the 5 -year (8) and the 100-year (11) precipitation events. These two recurrence intervals were examined for basin characteristic variations. For the 5 -year recurrence interval events, basin characteristics were important, and slope provided the best correlation coefficient $r=0.99$ (fig. 11). Permeability resulted in an $\mathrm{r}=0.68$, whereas mean annual precipitation resulted in $r=0.07$. This provides evidence that for the lower recurrence intervals, some basin characteristics have a significant impact on peak discharge. For the 100-year event group, the correlation coefficient for slope was not as good with $\mathrm{r}=0.25$. The correlation coefficients for permeability, $r=0.20$, and for precipitation $\mathrm{r}=0.11$ were low.

Another informative comparison is between time of concentration (Tc) and Q/A. For the 5-year recurrence interval (fig. $12 A)$ the relation is $(\mathrm{r}=0.77)$ with $\mathrm{Q} / \mathrm{A}$ decreasing as $\mathrm{Tc}$ increases. For the 100-year events, a weaker relation exists $(\mathrm{r}=-0.48)$; (fig. 12B). Additional high recurrence interval (5-, 10-, 25-, 50-, and 100-year) precipitation/discharge data are needed to confirm the relations suggested above. Discharge data with attendant basin-wide precipitation data from precipitation-radar estimates provides a unique opportunity to study the effects of basin characteristics on the relation between precipitation recurrence intervals and discharge recurrence intervals.

\section{0/A Equations for Estimating Discharge-Frequency Values for Small Basins}

Equations for computing discharge-frequency values for small basins less than $32 \mathrm{mi}^{2}$ using $\mathrm{Q} / \mathrm{A}$ were developed using

(A) Precipitation-Recurrence Interval in relation to Q/A (for all 28 basins)

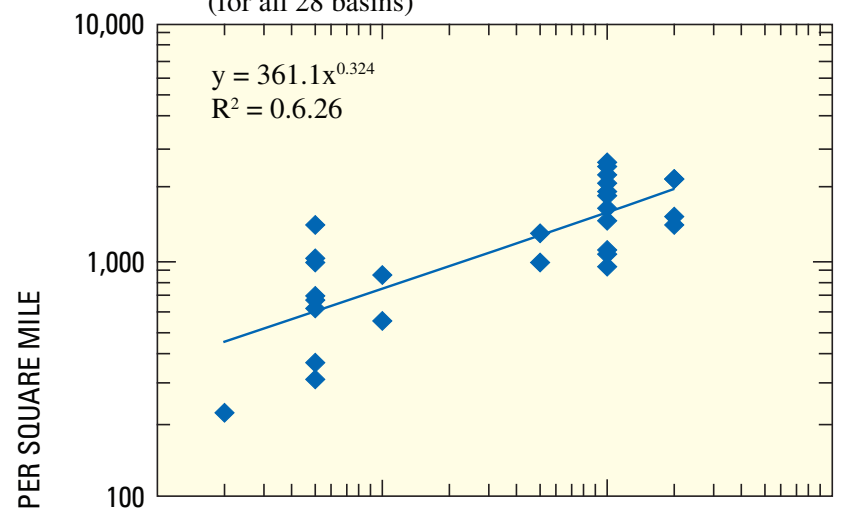

(B) Precipitation-Recurrence Interval in relation to Q/A

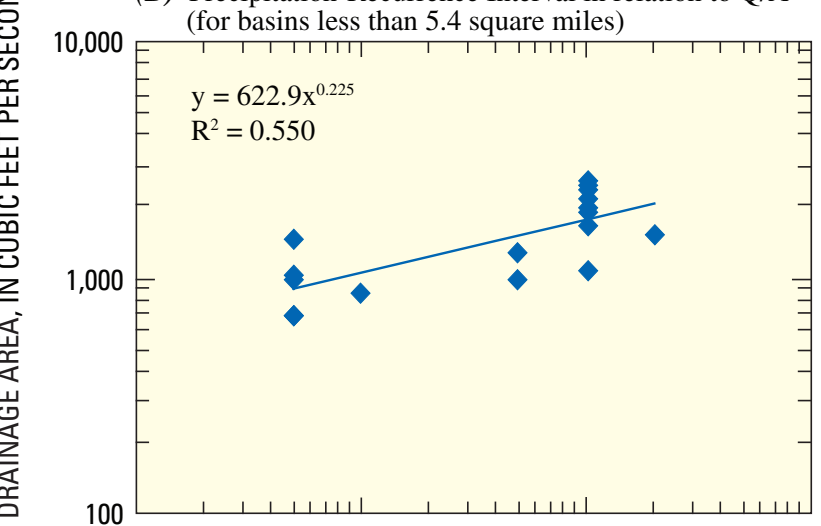

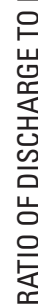

(C) Precipitation-Recurrence Interval in relation to $\mathrm{Q} / \mathrm{A}$ (for basins greater than 5.4 and less than 32 square miles)

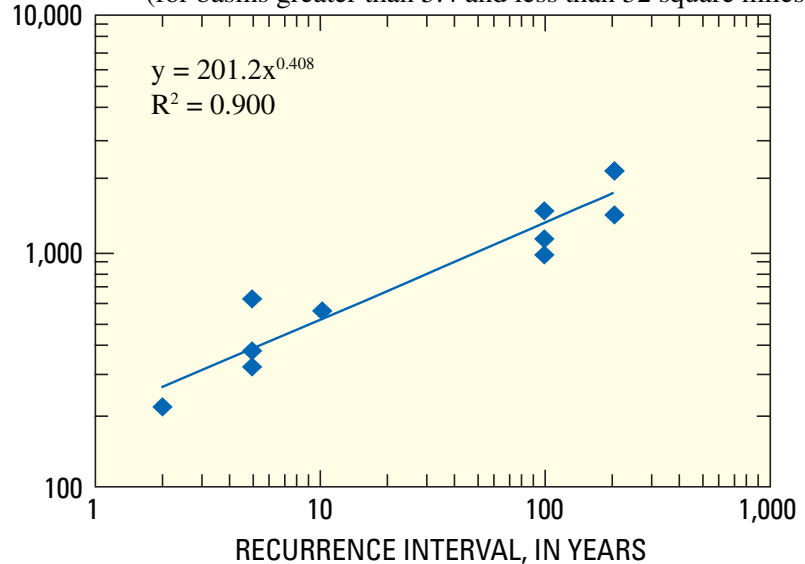

Figure 9. Relation between the ratio of discharge/drainage area $(Q / A)$ values and precipitation-recurrence intervals, for $(A)$ all basins; $(B)$ basins less than 5.4 square miles ; and $(C)$ basins 5.4 to 32 square miles. 
(A) Ratio of discharge/drainage area $(\mathrm{Q} / \mathrm{A})$ and precipitation/ precipitation-measurement-curve recurrence intervals and stream-gaged-data log Pearson III (LP3) recurrence intervals for basins less than 5.4 square miles

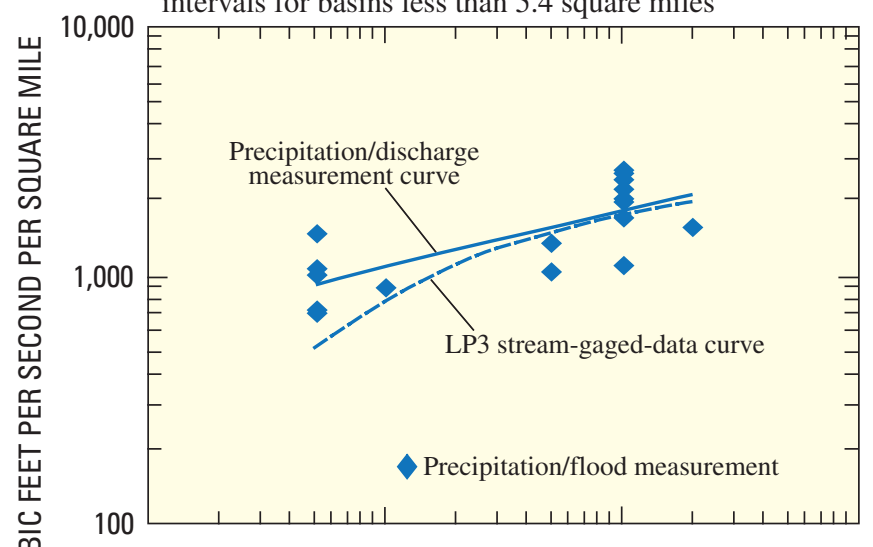

(B) Ratio of discharge/drainage area $(\mathrm{Q} / \mathrm{A})$ and precipitation/ precipitation-measurement-curve recurrence intervals and stream-gaged-data log Pearson III (LP3) recurrence intervals for basins greater than 5.4 and less than 32 square 10,000 miles

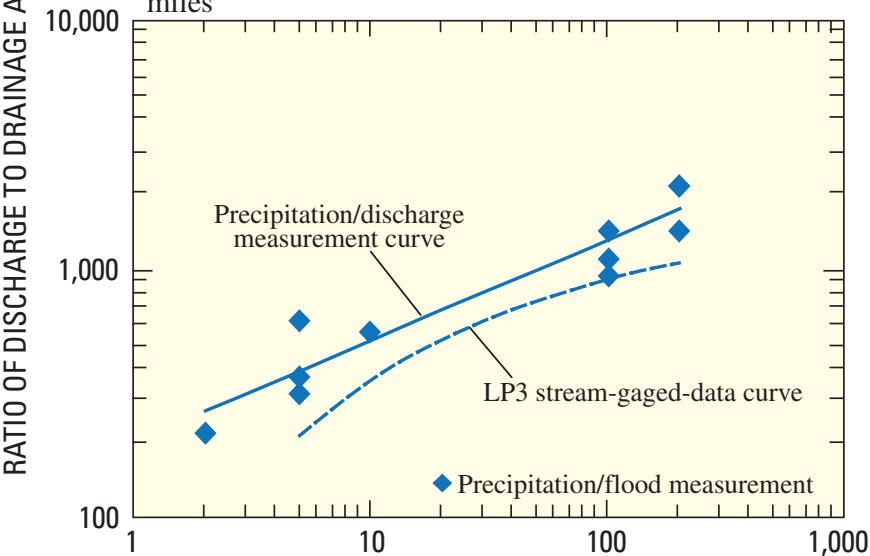

PRECIPITATION OR FLOOD RECURRENCE INTERVAL, IN YEARS

Figure 10. Relation between ratio of discharge/drainage area $(\mathrm{Q} / \mathrm{A})$ and precipitation-recurrence intervals and stream gageddata log Pearson III distribution (LP3) recurrence intervals for $(A)$ basins less than 5.4 square miles and $(B)$ basins between 5.4 and 32 square miles.

an alternative discharge-frequency analysis method instead of the conventional regional discharge-frequency analysis method (fig. 13). The conventional method consists of performing individual frequency analyses on each stream-gaging-station's annual peak-discharge series using the Interagency Advisory Committee on Water Data (1981) Bulleting 17B. If a station has less than 10 years of data, its discharge-frequency analysis is not used in the regional analysis. In addition, the error of estimating the t-year discharge-frequency value at each station rapidly increases with decreasing station record length for low probability events. After the t-year discharge value is determined for all qualifying stations, those values become the dependent variable in a multiple regression analysis with basin characteristic as independent variables. A logarithmic transformation of the data results in an equation in the form of:

$$
\mathrm{Q}_{\mathrm{t}-\text { year }}=\mathrm{K} \mathrm{w}^{\mathrm{a}} \mathrm{X}^{\mathrm{b}} \mathrm{y}^{\mathrm{c}} \mathrm{z}^{\mathrm{d}} \text {, }
$$

where $\mathrm{K}$ is the intercept and $\mathrm{w}$ is equal to the drainage area and usually is the dominant variable in the equation, and $\mathrm{x}, \mathrm{y}$, and $\mathrm{z}$ are other basin characteristics.

In the alternative method (fig. 13), all the peak-discharge data are utilized, no matter how long the individual station record is. Each discharge is considered an independent event. The annual maximum-discharge value for each occurrence is divided by the drainage area that contributed to that discharge to obtain Q/A. Each of these Q/A values, along with their respective basin characteristics (minus drainage area) are placed in a large single data set. In this analysis, that large data set was subdivided into two smaller sets, one set with initial drainage areas of less than $5.4 \mathrm{mi}^{2}$, and the other set with drainage areas from 5.4 to $32 \mathrm{mi}^{2}$. Each of these two subsets of the original data set were copied three times (the number of remaining basin characteristics), and each copy divided into quartiles for each of the basin characteristics. The Q/A values in each quartile were ranked and their rank-probability (RP) value was computed:

$$
\mathrm{RP}=(\operatorname{rank} /(\mathrm{n}+1),
$$

where $\mathrm{n}$ is the number of Q/A values in that quartile.

Then the t-year Q/A values, with basin characteristics, were selected from each of the three quartile groups. Windows of rank-probability values that were 0.10 wide were used to select Q/A values for the 2-, 5-, 10-, 25-, 50-, 100-, and 200year recurrence intervals. For example, Q/A values for the 100-year recurrence interval with rank/probabilities between 0.005 and 0.015 were selected for each of the quartiles of each of the three basin and climatic characteristics (table 3). For the 12 groups involved (three basin characteristics and four quartiles for each basin characteristic) for any one recurrence interval, this selection resulted in approximately 36 to 60 events with Q/A, permeability, channel slope, and mean annual precipitation for each t-year event. There was a good

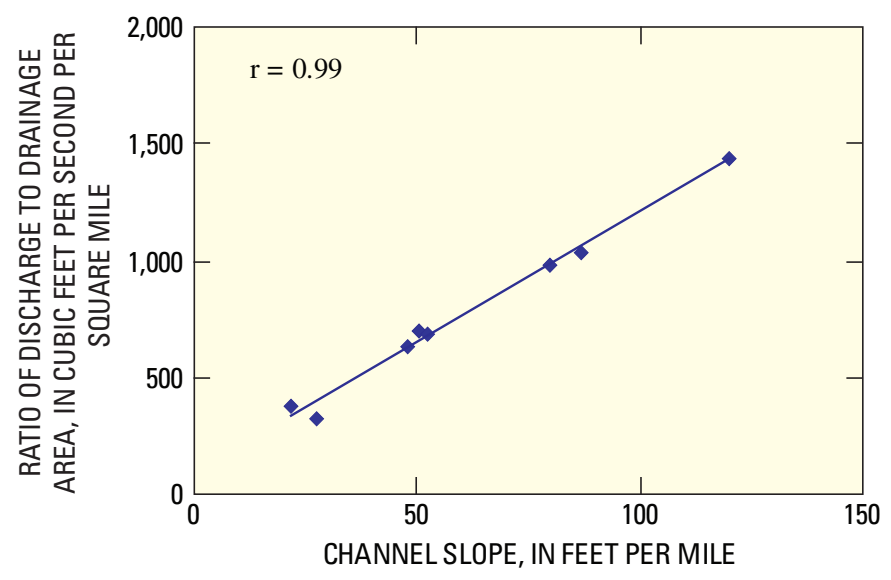

Figure 11. Relation between ratio of discharge/drainage area $(0 / A)$ and channel slope for basins less than 5.4 square miles using 5 -year precipitation-recurrence interval. 
(A) Ratio of discharge/drainage area (Q/A) and time of concentration for 5-year precipitation-recurrence interval

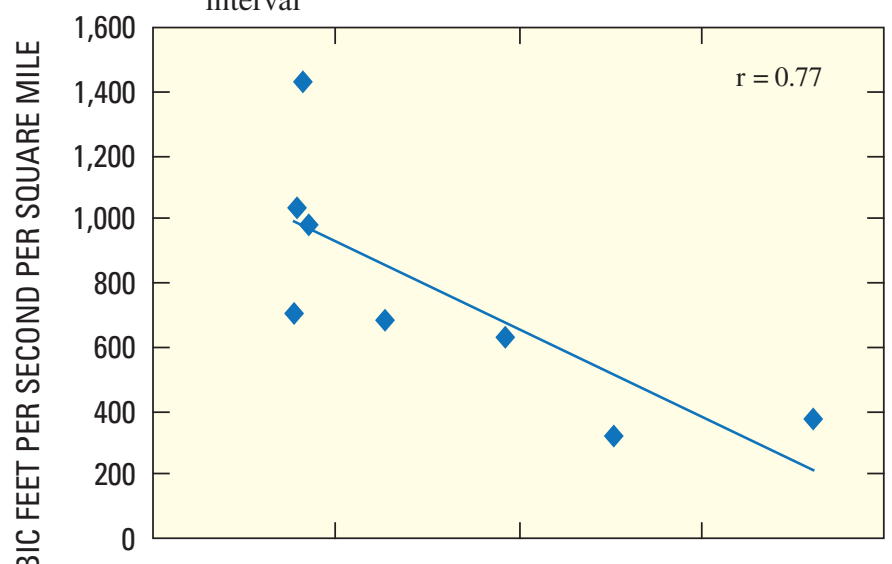

(B) Ratio of discharge/drainage area $(\mathrm{Q} / \mathrm{A})$ and time of concentration for 100-year precipitation-recurrence interval

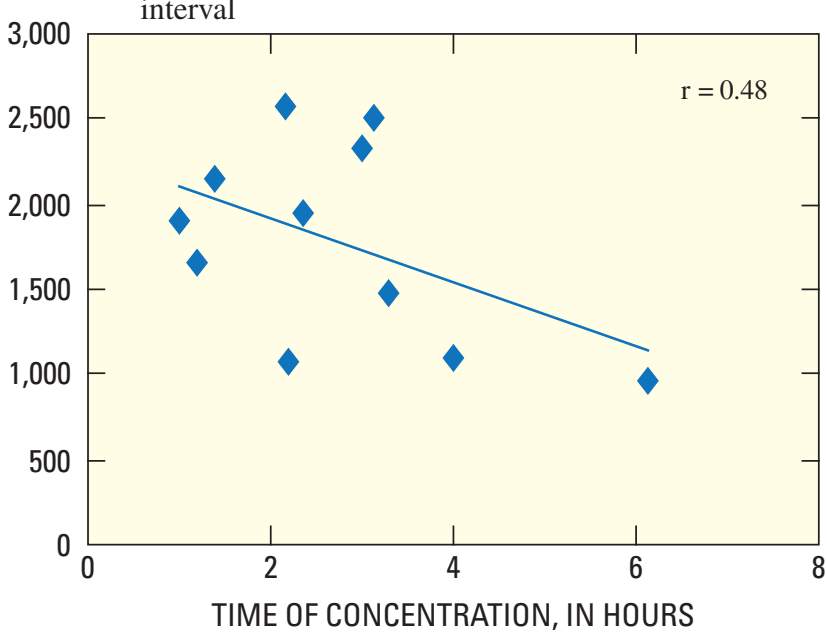

Figure 12. Relation between ratio of discharge/drainage area $(\mathrm{Q} / \mathrm{A})$ and time of concentration for $(A) 5$-year precipitationrecurrence interval and $(B)$ 100-year precipitation-recurrence interval.

probability that some of the events would be duplicates, and the number of duplicates increased with increasing recurrence interval. This would occur when the same event was selected from one or more basin characteristic group based on its rank probability. All duplicate events were discarded within a recurrence-interval group. Each recurrence-interval group had between 18 and 44 events remaining after duplicates were removed. A stepwise multiple regression analysis was run for each recurrence-interval group. A logarithmic transformation of the dependent and independent data resulted in an equation in the form of:

$$
(\mathrm{Q} / \mathrm{A})_{\mathrm{t}-\mathrm{year}}=\mathrm{K} \mathrm{x}^{\mathrm{a}} \mathrm{y}^{\mathrm{b}} \mathrm{z}^{\mathrm{c}} \text {. }
$$

The resulting regression equations for basins less than $5.4 \mathrm{mi}^{2}$ and for basins between 5.4 and $32 \mathrm{mi}^{2}$ and are listed in table 4 . The average uncertainty in log units, for all the $\mathrm{Q} / \mathrm{A}$ equations (2-year to 200-year) for the equations for basins less than $5.4 \mathrm{mi}^{2}$ was $0.0944 \log$ units, and for basins between 5.4 and $32 \mathrm{mi}^{2}, 0.1346 \log$ units. Soil permeability and mean annual precipitation were the dominant basin characteristics in the multiple regression analyses.

\section{Comparison of Equations Used to Estimate Discharge Frequency for Small Rural Basins with Precipitation-/ Discharge-Frequency Measurements}

The 28 precipitation-/discharge-frequency measurements in this report were compared with the values generated by the three groups of equations, the rational method, the Kansas discharge-frequency equations (KFFE) from Rasmussen and Perry (2000), and the equations developed in this report using the Q/A relations for small stream gaged basins in Kansas. This provided an indirect method of comparing precipitation frequency with the resulting discharge frequency. The measured discharge recurrence interval used in each comparison was the precipitation-recurrence interval determined from the weather-radar estimates of precipitation depth and intensity and the time of concentration (Tc) for each basin. The same recurrence interval was used in determining which recurrenceinterval discharge-frequency equation to use. The comparison between the measured discharge and the computed discharge from the rational method is shown in figure 14, the discharge from the KFFE is shown in figure 15, and the discharge from the $\mathrm{Q} / \mathrm{A}$ equations is shown in figure 16.

The rational method (fig. 14) grossly underestimates discharges less than approximately $5,000 \mathrm{ft}^{3} / \mathrm{s}$, but improves to near equality above $10,000 \mathrm{ft}^{3} / \mathrm{s}$. The slope of the best fit line was greater than a $1: 1$ ratio $\left(y=0.0722 x^{1.235}\right)$. Comparing the KFFE to the rational method gave opposite results, with the lower computed discharges nearly equal to the measured discharges, and the higher computed discharges being much less than the measured discharges; the slope of the line was less than a 1:1 ratio $\left(y=5.9103 x^{0.7475}\right)$. Comparing the measured and $\mathrm{Q} / \mathrm{A}$ equation computed discharge displayed the best equality from low to high discharges of the three methods. The slope of the line was nearly a $1: 1$ ratio $\left(y=0.9844 x^{0.9677}\right)$. The Q/A equation standard error of prediction averaged $0.1346 \mathrm{log}$ units for the basins that were in the 5.4- to 32- $\mathrm{mi}^{2}$ group, and $0.0944 \log$ units for the basins less than $5.4 \mathrm{mi}^{2}$. The KFFE standard error averaged $0.2107 \log$ units for the for less-than$30-\mathrm{mi}^{2}$ equations. Using the $\mathrm{Q} / \mathrm{A}$ equations for determining discharge-frequency values for ungaged sites seems to be a good alternative to the other two methods. 

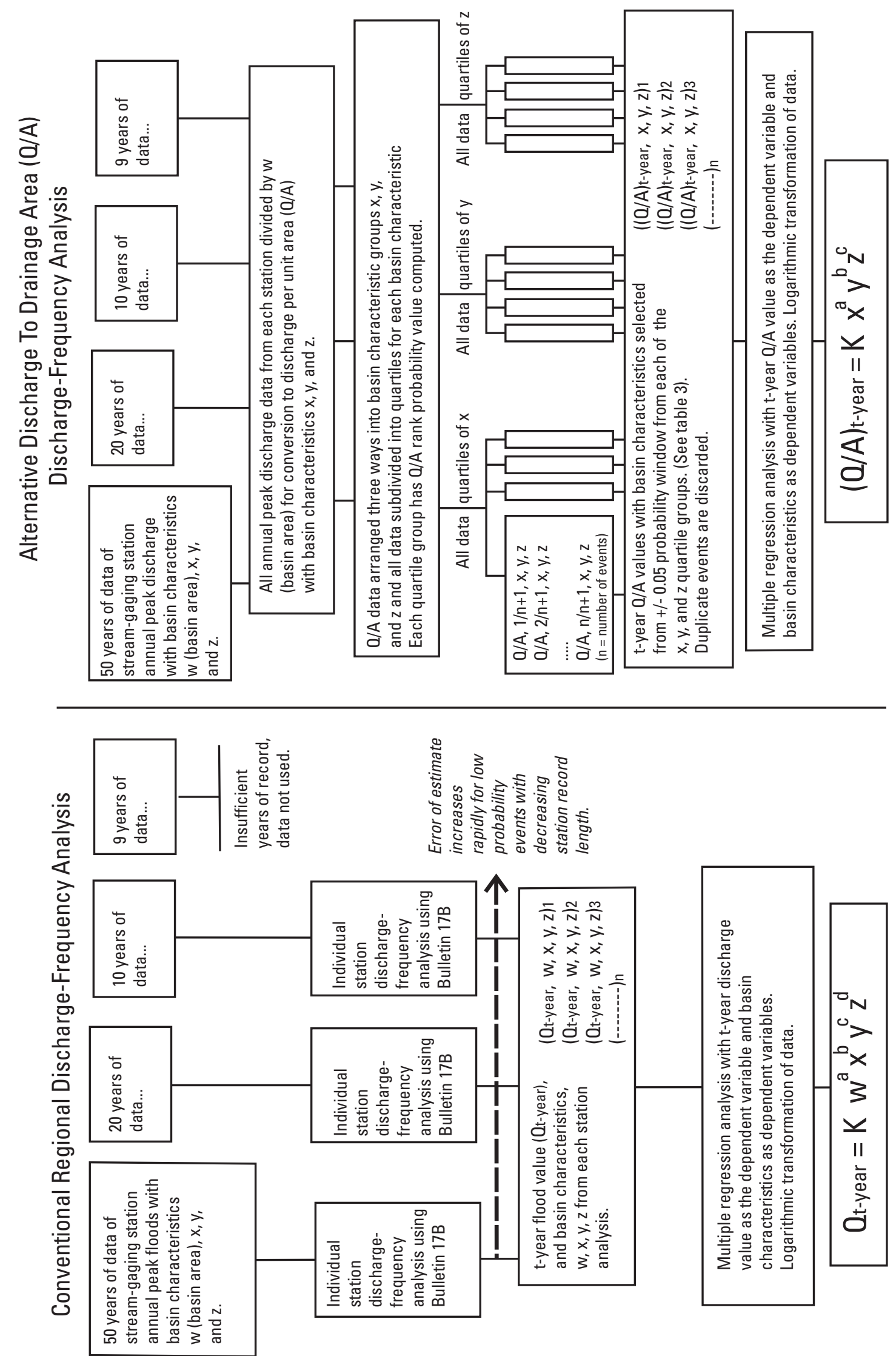


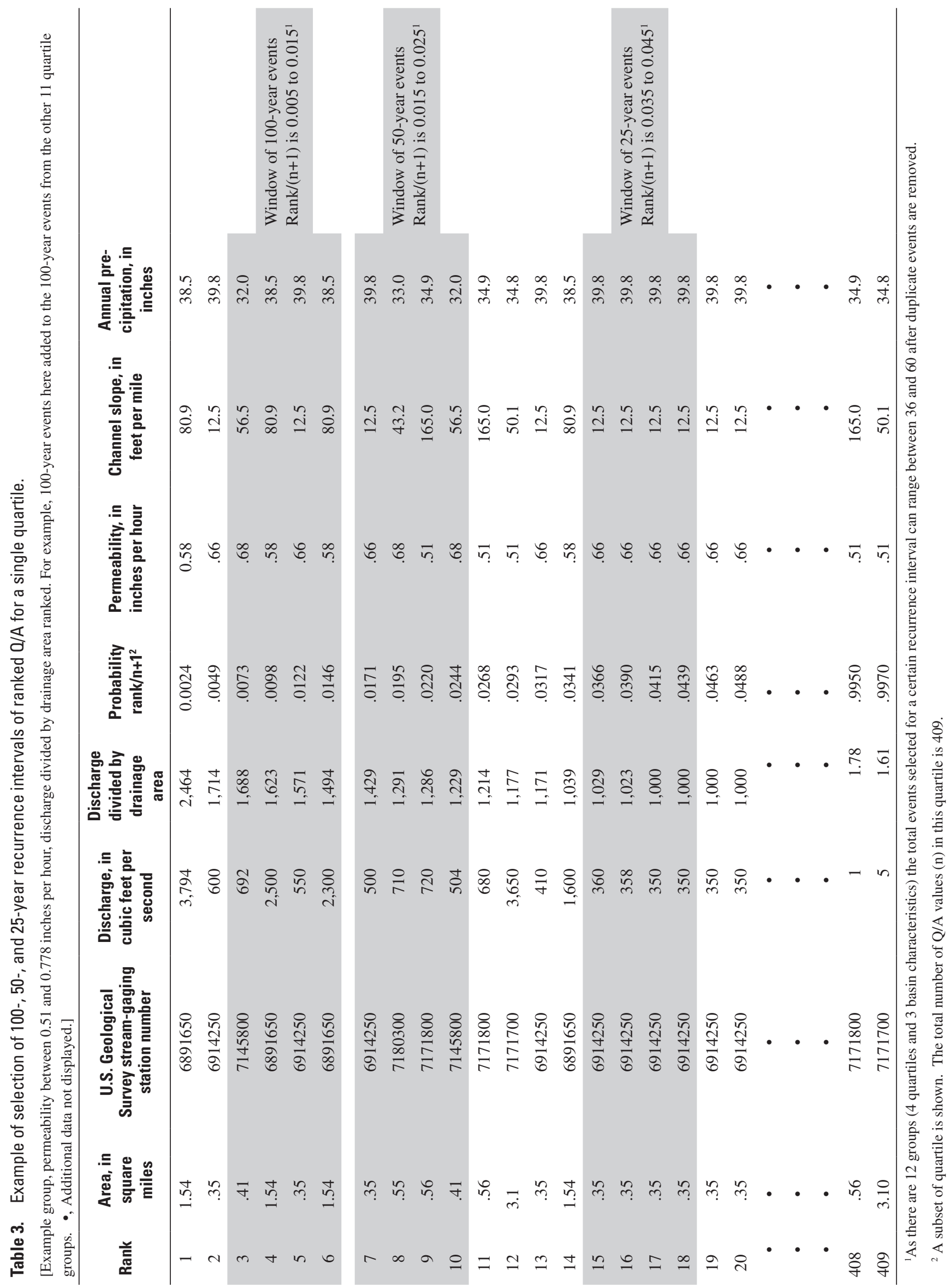


Table 4. Multiple linear regression variables and coefficients for discharge/drainage area $(\mathrm{Q} / \mathrm{A})$ discharge-frequency equations developed in this report.

[n/a, not available; RMSE, root mean squared error; $\mathrm{R}^{2}$, correlation coefficient squared; $\mathrm{p}$-values, probability that value obtained occured by chance]

\begin{tabular}{|c|c|c|c|c|c|c|c|}
\hline & \multicolumn{7}{|c|}{ Recurrence interval, in years } \\
\hline & 2 & 5 & 10 & 25 & 50 & 100 & 200 \\
\hline \multicolumn{8}{|c|}{ Less than 5.4 square miles } \\
\hline Intercept & 1.344 & 0.792 & 1.8259 & 1.6804 & 2.3544 & 2.2993 & 3.2674 \\
\hline Permeability & -.6235 & -.5701 & -.2388 & -.2151 & -.2297 & -.22223 & -.4523 \\
\hline Slope & $\mathrm{n} / \mathrm{a}$ & $\mathrm{n} / \mathrm{a}$ & .1374 & .109 & $\mathrm{n} / \mathrm{a}$ & $\mathrm{n} / \mathrm{a}$ & $\mathrm{n} / \mathrm{a}$ \\
\hline Precipitation & .5429 & .4975 & .4871 & .7289 & .463 & .5748 & $\mathrm{n} / \mathrm{a}$ \\
\hline RMSE & .1447 & .1084 & .09326 & .07157 & .08598 & .09552 & .06177 \\
\hline $\mathrm{R}^{2}$ & .578 & .6911 & .6472 & .7291 & .5562 & .5189 & .8086 \\
\hline $\begin{array}{l}\text { Degree of } \mathrm{R}^{2} \\
\text { freedom }\end{array}$ & 44 & 34 & 38 & 33 & 35 & 24 & 18 \\
\hline $\mathrm{p}$-value & 0 & 0 & 0 & 0 & 0 & 0 & 0 \\
\hline \multicolumn{8}{|c|}{5.4 to 32 square miles } \\
\hline Intercept & -1.3197 & 1.6545 & 1.2797 & 1.7228 & 2.0277 & 2.0799 & 1.4147 \\
\hline Permeability & & -.5858 & -.3022 & -.2649 & -.3104 & -.2991 & -.302 \\
\hline Slope & .325 & $\mathrm{n} / \mathrm{a}$ & $\mathrm{n} / \mathrm{a}$ & $\mathrm{n} / \mathrm{a}$ & $\mathrm{n} / \mathrm{a}$ & $\mathrm{n} / \mathrm{a}$ & .3143 \\
\hline Precipitation & 1.8723 & .3016 & .7289 & .5757 & .4564 & .4977 & .7321 \\
\hline RMSE & .1808 & .1596 & .1198 & .1267 & .1007 & .1192 & .1353 \\
\hline $\mathrm{R}^{2}$ & .5915 & .4498 & .5631 & .4762 & .5374 & .4316 & .5246 \\
\hline $\begin{array}{l}\text { Degree of } \mathrm{R}^{2} \\
\text { freedom }\end{array}$ & 40 & 43 & 42 & 35 & 34 & 29 & 33 \\
\hline $\mathrm{p}$-value & 0 & 0 & 0 & 0 & 0 & 0 & 0 \\
\hline
\end{tabular}

\section{Summary}

The purpose of a study by the U.S. Geological Survey, in cooperation with the Kansas Department of Transportation, was to improve the uncertainty of peak-discharge estimates for basins less than $32 \mathrm{mi}^{2}$ by using the precipitation-recurrence interval to estimate the discharge-recurrence interval for ungaged sites. Discharge measurements made from August 2003 to May 2007 at 28 sites were used in this analysis to relate precipitation-recurrence interval with dischargerecurrence interval. Precipitation for each of these discharge measurements was estimated from weather-radar estimates of precipitation and/or from nearby raingages. Time of concentration for the ungaged sites was computed and used to select the precipitation duration and the recurrence interval, based on precipitation frequency maps and graphs. The discharge to drainage area ratio $(\mathrm{Q} / \mathrm{A})$ for each event was assigned that precipitation-recurrence interval, which also was assumed to be the discharge-recurrence interval.

Precipitation-recurrence interval and Q/A for all 28 measured events resulted in a correlation coefficient of 0.79. Using basins less than $5.4 \mathrm{mi}^{2}$ only the correlation decreases to 0.74 . However, when basins greater than 5.4 and less than $32 \mathrm{mi}^{2}$ are examined the relation improves to a correlation coefficient of 0.95 .

There were enough events for the 5-year (8 events) and the 100-year (11 events) recurrence intervals to examine the effect of basin characteristics on the $\mathrm{Q} / \mathrm{A}$ values for basins less than $32 \mathrm{mi}^{2}$. At the 5-year precipitation-/discharge-recurrence interval, channel slope was a significant predictor $(\mathrm{r}=0.99)$ of $\mathrm{Q} / \mathrm{A}$. Permeability $(\mathrm{r}=0.68)$ also had a significant effect on Q/A values for the 5-year recurrence interval. At the 100-year recurrence interval, permeability, channel slope, and mean annual precipitation did not correlate as well as the 5-year recurrence interval discharges. Time of concentration is an important factor in determining Q/A for the 5-year and 100year events, with greater times to concentration resulting in lower $\mathrm{Q} / \mathrm{A}$ values. For the other recurrence intervals $(2,10,25$, 50 , and 200), there was not sufficient data to develop relations. Additional precipitation/discharge events are needed to better develop relations between precipitation recurrence interval and peak flow.

Discharge frequency relations in Kansas for small basins with areas less than $32 \mathrm{mi}^{2}$ were examined using the discharge per unit area $(\mathrm{Q} / \mathrm{A})$ concept. Stream-gage discharge records were used to develop equations for $\mathrm{Q} / \mathrm{A}$ values using 


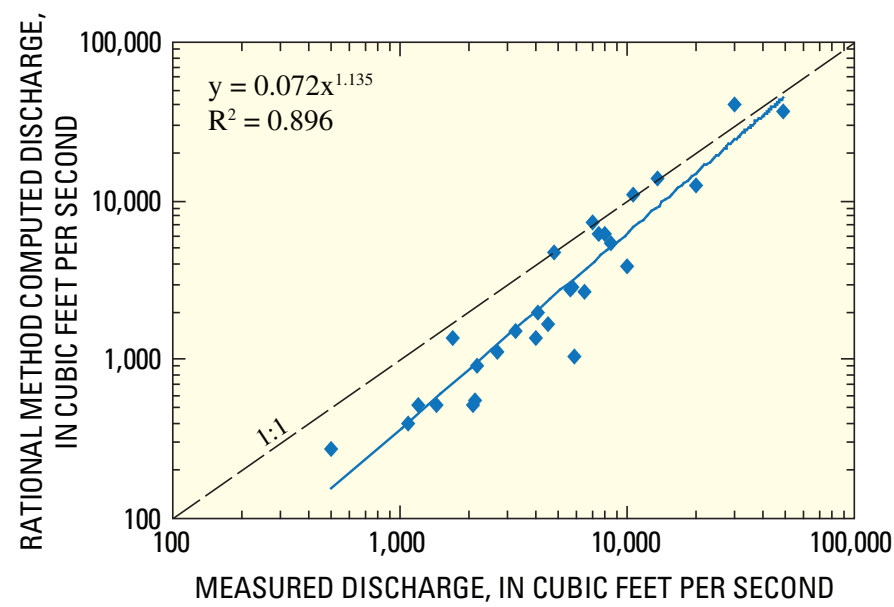

Figure 14. Relation between measured discharge and computed discharge values using the rational method.

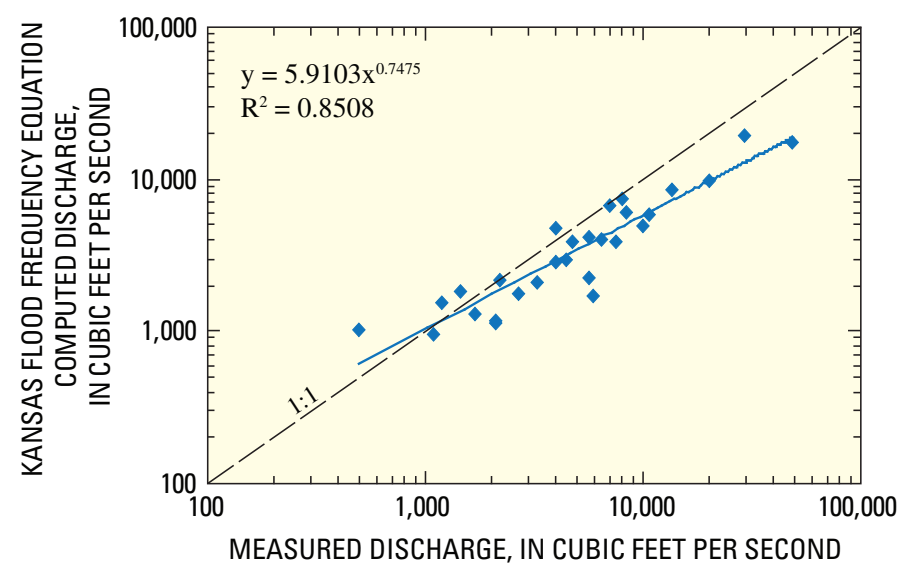

Figure 15. Relation between measured discharge and computed discharge values using Kansas discharge-frequency equations (KFFE).

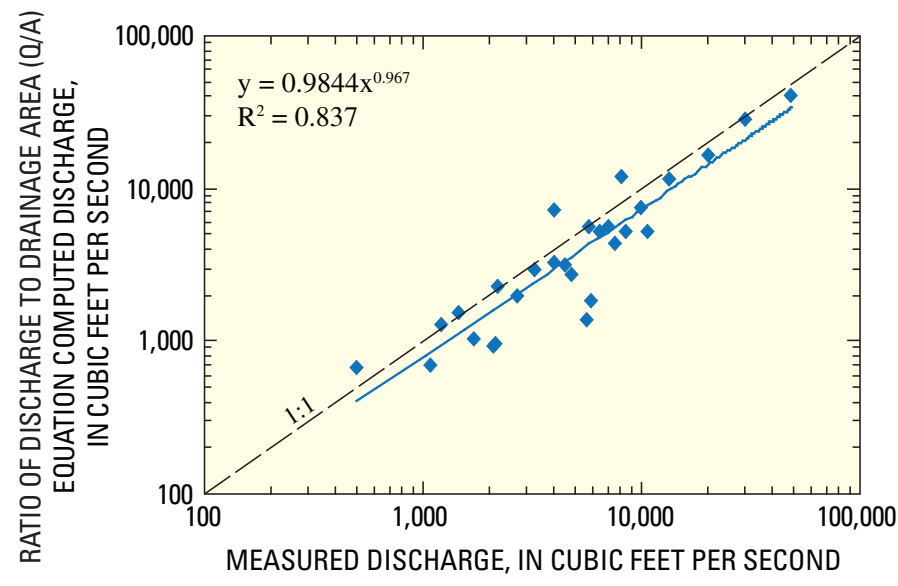

Figure 16. Relation between measured discharge and computed discharge values using the discharge/drainage area ( $0 / A)$ discharge-frequency equations developed in this report. data from 128 basins with variable soil permeability, channel slope, and mean annual precipitation. Two groups of basins were examined, those less than $5.4 \mathrm{mi}^{2}$, and basins between 5.4 and $32 \mathrm{mi}^{2}$. The Q/A data were ranked for each quartile of each of three basin characteristics. Data from each quartile were selected for each recurrence interval using a 0.10 window. Multiple regression analyses were then used to develop an equation for each recurrence interval for both basin groups. Soil permeability and mean annual precipitation were the dominant basin characteristics in the multiple regression analyses.

The 28 precipitation-/discharge-frequency measurements in this report were compared with the values generated by the Q/A equations for small stream gaged basins in Kansas as well as the rational method and the Kansas discharge-frequency equations (KFFE). The frequency used in each equation comparison was the precipitation frequency determined from the weather-radar estimates of precipitation depth and intensity and the time of concentration (Tc) for each basin. This provided an indirect method of comparing precipitation frequency with the resulting discharge frequency. The 28 measured sites compared best with the results from the Q/A equations. Plots of measured discharges and $\mathrm{Q} / \mathrm{A}$ computed discharges resulted in nearly a $1: 1$ ratio (best fit line $\mathrm{y}=0.9844 \mathrm{x}^{0.9677}$ ). The $\mathrm{Q} / \mathrm{A}$ equation standard error of prediction averaged $0.1346 \log$ units for the 5.4- to 32- $\mathrm{mi}^{2}$ group, and $0.0944 \log$ units for the group that was less than $5.4 \mathrm{mi}^{2}$. The KFFE standard error averaged $0.2107 \log$ units for the less-than-30- $\mathrm{mi}^{2}$ equations. Using the $\mathrm{Q} / \mathrm{A}$ equations for determining discharge-frequency values for ungaged sites seems to be a good alternative to the other two methods when compared to precipitation-/discharge-frequency measurements.

Additional high recurrence interval (5-, 10-, 25-, 50-, and 100-year) precipitation/discharge data are needed to confirm the relations suggested. Discharge data with attendant basinwide precipitation data from precipitation-radar estimates provides a unique opportunity to study the effects of basin characteristics on the relation between precipitation-recurrence intervals and discharge-recurrence intervals.

\section{References Cited}

Benson, M.A., 1952, Characteristics of frequency curves based on a theoretical 1000-year record: U.S. Geological Survey Water-Supply Paper 1543-A, p. 51-74.

Benson, M.A., and Dalrymple, Tate, 1967, General field and office procedures for indirect discharge measurements: Techniques of Water-Resources Investigations of the United States Geological Survey, book 3, chap. A1, 30 p.

Bodhaine, G.L., 1968, Measurement of peak discharge at culverts by indirect methods: Techniques of Water-Resources Investigations of the United States Geological Survey, book 3, chap. A3, 60 p. 
Clement, R.W., 1983, Improvement of flood-frequency estimates for selected small watersheds in eastern Kansas using a rainfall-runoff model: U.S. Geological Survey WaterResources Investigations Report 83-4110, 22 p.

Dalrymple, Tate, and Benson, M.A., 1968, Measurement of peak discharge by the slope-area method: Techniques of Water-Resources Investigations of the United States Geological Survey, book 3, chap. A2, 12 p.

Hardison, C.H., 1974, Generalized skew coefficients of annual floods in the United States and their application: Water Resources Research, v. 10, issue 4, p. 745-752.

Hayes, D. C., and Young, R. L., 2006, Comparison of peak discharge and runoff characteristic estimates from the rational method to field observations for small basins in central Virginia: U.S. Geological Survey Scientific Investigations Report 2005-5254, 38 p.

Hodgkins, G.A., Hebson, Charles, Lombard, P.J., and Mann, Alexander, 2007, Comparison of peak-flow estimation methods for small drainage basins in Maine: U.S. Geological Survey Scientific Investigations Report 2007-5170, $32 \mathrm{p}$.

Hulsing, Harry, 1967, Measurement of peak discharge at dams by indirect methods: Techniques of Water-Resources Investigations of the U.S. Geological Survey, book 3, chap A5, 29 p.

Interagency Advisory Committee on Water Data, 1981, Guidelines for determining flood flow frequency: Washington, D.C., Bulletin 17B of the Hydrology Committee, 28 p.

Jennings, M.E., Thomas, W.O., and Riggs, H.C., 1994, Nationwide summary of U.S. Geological Survey regional regression equations for estimating magnitude and frequency of floods for ungaged sites, 1993: U.S. Geological Survey Water-Resources Investigations Report 94-4002, $196 \mathrm{p}$.

Linsley, R.K. Jr., Kohler, M.A., and Paulhus, J.L.H., 1958, Hydrology for Engineers: McGraw-Hill, Inc. New York, p. $82-85$.

Maidment, D.R., Editor, 1992, Handbook of Hydrology: McGraw-Hill, Inc., New York, p. 9.14-9.17.
Matthai, H.F., 1967, Measurement of peak discharge at width contractions by indirect methods: Techniques of WaterResources Investigations of the U.S. Geological Survey, book 3, chap. A4, 44 p.

National Oceanic and Atmospheric Administration, 2007, Climatological data for Kansas: National Climatic Data Center, Asheville, North.Carolina, (various months).

Ponce, V.M., 1989, Engineering Hydrology_Principles and practices: Englewood Cliffs, NJ, Prentice-Hall., 612 p.

Rasmussen, P.P., Perry, C.A., 2000, Estimation of peak streamflows for unregulated rural streams in Kansas: U.S. Geological Survey Water-Resources Investigations Report 00-4079, 33 p.

Rose, Frederick A., Hwang, Guang-Jiunn, 1985, Study of differences between streamflow frequency and rainfall frequency for small rural watersheds: University of Kentucky, Office of Engineering Services, (Bulletin) UKY BU, p. 203-214.

Serafin, R.J., and Wilson, J.W., 2000, Operational weather radar in the United States: Progress and opportunity: Bulletin of the American Meteorological Society, v. 81, no. 3, p. 501-518.

Tasker, G.D., and Stedinger, J.R., 1986, Regional skew with weighted LS regression: Journal of Water Resources Planning and Management, v. 112, book 2, p. 225-237.

Thiessen, A.H., 1911, Precipitation averages for large areas: Monthly Weather Review, p. 1,082-1,089.

U.S. Army Corps of Engineers, 2006, HEC-RAS Version 4.0.0 Beta, http://www.hec.usace.army.mil/software/hec-ras/ hecras-download.html.

U.S. Weather Bureau, 1961, Rainfall frequency atlas of the United States for durations from 30 minutes to 24 hours and return periods from 1 to 100 years: Technical Paper No. 40, Washington, D.C.

Williams, B.G., 1922, Flood discharge and the dimensions of spillways in India: The Engineer (London), v. 121, p. 321-322, September 1922.

Young, C.B., and McEnroe, B.M., 2006, Updated Precipitation Frequency Estimates for Kansas City: Comparison with TP-40 and HYDRO-35: Journal Hydrologic Engineering, v. 11, issue 3, p. 206-213 (May/June 2006). 
Publishing support provided by:

Rolla Publishing Service Center

For more information concerning this publication, contact:

Director, USGS Kansas Water Science Center

4821 Quail Crest Place

Lawrence, KS 66049

(785) 842-9909

Or visit the Kansas Water Science Center Web site at: http://ks.water.usgs.gov 
Top back cover photograph. Seth Studley (USGS Hydrologist) measuring the opening of a relief culvert on Upper Rock Creek, Jackson County, Kansas (photograph by Charles A. Perry, U.S. Geological Survey).

Bottom back cover photograph. Damaged culvert on Little Slough Creek tributary, Jefferson County, Kansas, because of excessive flow over the road on October 2, 2005 (photograph by Charles A. Perry, U.S. Geological Survey). 


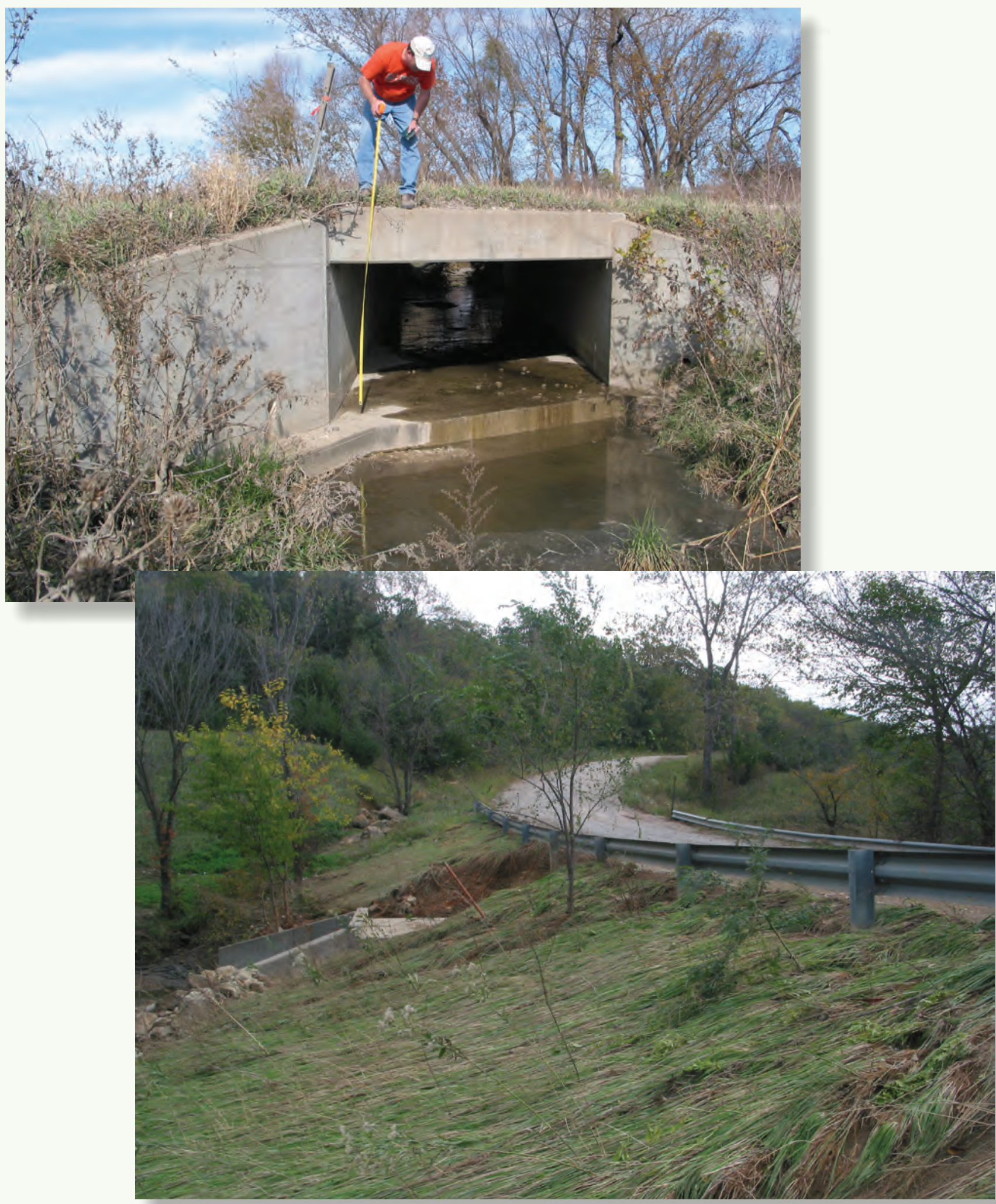

